\title{
ENTre AtLántico y MediterRáneo: LA CIUDAD DE TÁNGER COMO MOVIMIENTO Y LOS PAISAJES DE LA TEORÍA
}

\author{
Between Atlantic and Mediterranean: the city of Tangier \\ as movement and the landscape of theory \\ Entre Atlântico e Mediterrâneo: a cidade de Tanger \\ como movimento e as paisagens da teoria
}

\author{
OtTMAR ETte \\ Universidade de Potsdam, Potsdam, Alemanha \\ E-mail: ette@uni-potsdam.de
}

\section{RESUMEN}

Tánger es una ciudad que puede considerarse tanto como movimiento como en movimiento. Ubicada en la intersección de rutas, es un lugar de tránsito. Pero, como ninguna otra ciudad en las encrucijadas de movimientos transcontinentales actuales y pasados, Tánger se ha convertido en símbolo del movimiento en sí: del tránsito del conocimiento y su vectoricidad. En su historia y en su mito, Tánger no es territorial, sino vectorial: Tánger es tránsito. A partir de relatos del siglo XIV de Ibn Battūta, el peregrino más famoso del mundo árabe, Tánger se convertirá en el

EDITORES:

Regina Zilberman

Gerson Roberto Neumann

SUBMETIDO: 04.09 .2020

ACEITO: 22.10.2020

\section{COMO CITAR:}

ETTE, Ottmar. Entre Atlántico y Mediterráneo: la ciudad de Tánger como movimiento y los paisajes de la teoría. Rev. Bra. Lit. Comp., Porto Alegre, v. 23, n. 42, p. 63-90, jan./ abr., 2021. doi: https:// doi.org/10.1590/2596$304 \times 20212342 \mathrm{oe}$

http://www.scielo.br/rblc https://revista.abralic.org.br punto de partida de un viaje que, inducido por la nostalgia y añoranza, se extiende más allá de Meca y Medina. Tánger significa asimismo origen y procedencia, idea que se mantiene viva en la conciencia del lector. Sus relatos nos proporcionan datos fundamentales de una convivencia de las culturas, un saber con/vivir, y han contribuido en gran medida con tal saber, fundamental para organizar una convivencia en paz y en diferencia. Posteriormente, en el siglo XX, Severo Sarduy y Roland Barthes desvelan otras perspectivas de la historia y del mito de Tánger en el sentido de una vectoricidad, en continuidad con los escritos de Ibn Battūta. A partir de sus experiencias se hablará de Tanger Transit - y también se formulará la pregunta, por qué vías y cauces vectoriales se puede considerar un sitio arcaico, un sitio mítico, un sitio literario en movimiento, desde el movimiento y como movimiento. Trataremos de descubrir de qué modo se puede sustituir una historia del espacio por una del movimiento para poder desarrollar no solamente lógicas de lo móvil, sino también lógicas móviles y polilógicas que no se encuentran ancladas en sistemas de referencia estáticos.

PALABRAS CLAVE: Tánger; poéticas del movimiento; literatura entre-mundos; estudios transareales; movimiento vectorial.

\begin{abstract}
Tangier is a city that could be considered both as movement and in movement. Placed on a crossroad of routes, it is a place of transit. However, like no other city on the crossroads of past and current transcontinental movements, Tangier has been transformed into a symbol of movement itself: of transits of knowledge and its vectoriality. In its history and myth, Tangier is not territorial, but vectorial: Tangier is transit. From the histories of the fourth century by Ibn Battūta, the most famous peregrin of the Arab world, Tangier will be transformed in the starting point of a journey that, induced by nostalgia and longing, stretches beyond Mecca and Medina. Tangier means concomitantly origin and provenance, an idea that stays alive in the reader's consciousness. Its narratives provide us with fundamental data about the conviviality of cultures, and contribute at large to a convivial knowledge, fundamental to organizing an existence in peace and difference. Later on, in the twentieth century, Severo Sarduy and Roland
\end{abstract}


Barthes presented other angles of Tangier's history and myth in the sense of vectoriality, as a continuity to the writings of Ibn Battūta. From their experiences we will talk about Tanger Transit - and we will formulate the question through which paths and vectorial channels it is possible to consider an archaic place, a mythical place, a literary place in movement, from movement and as movement. We will manage to discover the way we can replace a history of space with a history of movement in order to develop not only logics of moving, but also moving logics and polilogics that are not anchored in static systems of reference.

KEYWORDS: Tangier; poetics of movement; literature between-worlds; transreal studies; verbal movements.

\title{
RESUMO
}

Tânger é uma cidade que se pode considerar tanto como movimento como em movimento. Situada na intersecção de rotas, é um lugar de trânsito. Mas, como nenhuma outra cidade nas encruzilhadas de movimentos transcontinentais atuais e passados, Tânger se transformou em símbolo do movimento em si: do trânsito do conhecimento e sua vetorialidade. Em sua história e mito, Tânger não é territorial, mas sim vetorial: Tânger é trânsito. A partir das histórias do século XIV de Ibn Battūta, o peregrino mais famoso do mundo árabe, Tânger se transformará no ponto de partida de uma viagem que, induzida pela nostalgia e saudade, se estende para além de Meca e Medina. Tânger significa ao mesmo tempo origem e procedência, ideia que se mantem viva na consciência do leitor. Suas narrativas nos proporcionam dados fundamentais de uma convivência das culturas, um saber com/viver, e contribuíram em grande medida com tal saber, fundamental para organizar uma convivência em paz e diferença. Posteriormente, no século XX, Severo Sarduy e Roland Barthes apresentaram outras perspectivas da história e do mito de Tânger no sentido de vetorialidade, como continuidade dos escritos de Ibn Battūta. A partir de suas experiencias se falará de Tanger Transit - e se formulará a pergunta, por quê vias e canais vetoriais é possível considerar um lugar arcaico, um lugar mítico, um lugar literário em movimento, a partir do movimento e como movimento. Trataremos de descobrir de que modo se pode substituir uma história do espaço por uma do movimento para poder desenvolver não apenas lógicas do móvel, mas também lógicas móveis e polilógicas que não se encontram ancoradas em sistemas de referência estáticos.

PALAVRAS-CHAVE: Tánger; poéticas do movimento; literatura entre-mundos; estudos transareais; movimento vetorial.

\section{TÁNGER EN CHINA}

\begin{abstract}
Entramos en la ciudad que cuenta con cuatro murallas: entre la primera y segunda habitan los siervos del rey encargados de guardar la ciudad por el día y por la noche [...] Entre el segundo y tercer recintos residen las tropas montadas y el virrey gobernador de la plaza. Intramuros de la tercera ccerca habitan os musulmanes y fue allí donde nos alojamos en casa del jeque Zahir ad-Din al-Qurlani. Los chinos ocupan el cuarto interior del cuarto muro, que es la parte mayor de las cuatro ciudades. [...] Cierto día en que estaba yo en la residencia de Zahir ad Din al-Qurlani he aquí que arribó un gran barco de cierto alfaquí muy apreciado allá. Se me pidió permiso para presentármelo y anunciaron: "Nuestro señor Qiwam ad Din as Sabti [el Ceutí]". Tal nombre me sorprendi y cuando compareció y empezamos a hablar tras los saludos creí conocerle. Lo escudriñé tan detenidamente que me dijo: Me observas como si me conocieras”. Respondí: “¿De qué país eres?” y él: “De Ceuta”. Yo agregué: “Y yo de Tánger”. Entonces volvió a saludarme y soltó el llanto hasta hacer que yo también llorase. Le inquirí: “¿Estuviste en la India?” Y contestó: "Sí, entré en Delhi, la capital”. Y al decirme eso le recordé y seguí: “¿No eres tú al-Buŝrī?”1
\end{abstract}

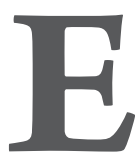

n esta escena de alta complejidad literaria acerca de un reencuentro, de una lagrimosa anagnórisis en el extranjero, se reconocen dos musulmanes que han estado de viaje la mayor parte de su vida. Ambos proceden de la misma región árabe no lejos del Estrecho de Gibraltar, han tenido un encuentro fugaz en la India y llegan a tratarse personalmente en el margen más oriental del área de influencia del islam. Nos hallamos muy lejos del Magreb, alejadísimos del Occidente, en la

1 Ibn Battūta: A través del Islam. Edición y raducción Serafin Fanjul y Federico Arbos. Madrid: Editora Nacional 1981, p. 729-730.
Véase asimismo Dunn, Ross E.: The Adventures of Ibn Battūta: A Muslim Traveler of the Fourteenth Century. Berkeley: University of
California Press 1986 y Hrbek, Ivan: The chronology of Ibn Battūta's travels. In: Archiv Orientalni (Praga) 30 (1962), S. 409-486. 
bella y enorme ciudad Qandschanfu, a la que el narrador en primera persona ha arribado después de viajar por un río, siguiendo la invitación del emperador de allí. La ciudad está situada en una llanura y rodeada de fecundos jardines y tiene cierto parecido al "oasis de la ciudad de Damasco", sin embargo, nos encontramos en China, en una ciudad que podríamos identificar en la actualidad como Jianshan en la provincia Zhejiang. El viajero, quien como visitante es recibido por todos los dignatarios ante las puertas de la ciudad, es en efecto Ibn Battūta, el peregrino árabe más famoso de todos los tiempos.

Ibn Battūta pasó largos períodos de su vida de viaje, el cual por su extensión e importancia se podría comparar más adecuadamente con el del veneciano Marco Polo. En ambos casos se trata de viajes anteriores al proceso histórico de aquellas fases de aceleramiento que en su conjunto conforman el perenne proceso de globalización ${ }^{4}$. Sin embargo, estos viajes son de gran envergadura para los conocimientos acerca del llamado «Viejo Mundo» en la primera fase de globalización acelerada: Cristóbal Colón extrajo de manera directa e indirecta gran parte de sus informaciones y convicciones de estos relatos 5 . Una vida de viaje, pero también toda una vida en busca de informaciones de actualidad: según las indicaciones del mismo Battūta, había partido en el año 1325 de su ciudad natal para volver de forma definitiva en 1353 a la región del actual Marruecos ${ }^{6}$. Este hijo tangerino se ha convertido en la personificación de los investigadores viajeros árabes.

Dos años después, en 1355, su relato de viaje no solo era famoso en el Oriente, sino también en Occidente, tal y como se sabe de boca de su editor actual, Ralf Elger, quien comenta que fue "realizado por un literato oriundo de Andalucía, Abu Abd Allah Muhammad ibn Dschuzayy al-Kalbi, por encargo del sultán marroquí, Abu Inan (quien fallece en 1358), según los relatos de viaje orales de Ibn Battūta"7. Da comienzo una larga historia de recepción de estos relatos puestos por escrito, revisados y editados un sinfín de veces, que no forma parte de la tesis por tratar aquí, pero que convierte a este viajero oriundo de Tánger en un garante no siempre indiscutido del conocimiento árabe sobre Asia, el África y extensas partes del Mediterráneo sur.

Ibn Battūta, quien muriera en 1368 o, según otras fuentes, recién en 1377, ofreció su relato como testimonio oral, así como lo hizo su «antecesor» occidental, Marco Polo - aunque no en cárceles genovesas; después de esto, los relatos fueron puestos en papel y salvaguardados para la posteridad. De la misma manera como al viajero veneciano, también a Ibn Battūta se le echaba en cara desde el principio haber inventado sus extensos viajes y no haberlos realizado personalmente. No obstante, la desconfianza de los que se han quedado en casa frente a los viajeros es tan antigua como la historia misma de la gente viajera. A diferencia del dicho alemán «Las mentiras tienen patas cortas $»$, el proverbio francés invita abiertamente a desconfiar de los travel-liars, los viajeros mentirosos: A beau mentir qui

\footnotetext{
2 Ibn Battūta: A través del Islam, op. cit., p. 729.

3 Ibid.

4 En cuanto a las distintas fases de globalización acelerada, véase el capítulo introductorio en Ette, Ottmar: TransArea. A Literary History of Globalization. Translated by Mark W. Person. Berlin - Boston: Walter de Gruyter 2016.

5 Cf. en relaciónc on la edición utilizada por Colón y los comentarios del genovés, la bella edición El libro de Marco Polo anotado por Cristóbal Colón. El libro de Marco Polo versión de Rodrigo de Santaella. Edición, introducción y notas de Juan Gil. Madrid: Alianza Editorial 1987.

6 Elger, Ralf: Prefacio. In: Ibn Battūta: Die Wunder des Morgenlandes, Reisen durch Afrika und Asien. Münch. In: C.H. Beck 2015, p. 7.

7 Ibid.
} 
vient de loin. Sin embargo, ¿qué tan importante es plantearse la pregunta, si Ibn Battūta realmente vio con sus propios ojos todo lo que describió?

A pesar de que incluso en la actualidad y apoyados en fuentes más fiables, siguen existiendo dudas más o menos fundadas de si en efecto se realizaron ciertas partes del viaje o incluso el viaje en su conjuntos, se tiene que tomar en consideración que aquí nos encontramos frente a un viajero que, aunque no haya llegado hasta el límite de China - describe con gran viveza y plasticidad un mundo que era conocido, aunque probablemente no familiar en el ámbito árabe del siglo XIV. Evitemos abordar el relato de viaje árabe con formas y normas de compenetración literaria provenientes de una tradición moderna del mundo occidental ya que no se pueden transferir así simplemente a literaturas extraeuropeas. La definición de «autor», «autoría $\gg$ «autoridad» no es ni transhistórica, ni transcultural.

El viaje de Ibn Battūta presenta sin lugar a dudas el saber de toda una época sobre el mundo de aquel entonces conocido por los eruditos y demuestra asimismo una conciencia de mundo (Weltbewusstein) que, como conciencia de los más diversos aspectos de la vida a escala mundial, es algo fuera de lo común en este espacio de tiempo (Zeitraum) - pese a estar anclado en el conocimiento y textos de referencia coetáneos. No hubo nadie en el mundo árabe del siglo XIV que hubiera podido estructurar y desarrollar el conocimiento de su época acerca de los aspectos políticos, sociales, religiosos y económicos o culturales del modo en que lo hiciera Ibn Battūta.

Aquí es determinante que su historia escenifica el conocimiento de su época en forma de un viaje, de un itinerario complejo, ya que los espacios de los que habla(n) su(s) relato(s) solamente se pueden trazar y desarrollar desde el movimiento. Por eso, así como sucede con Marco Polo, es de menor relevancia si el viajero ha visto todo aquello de lo que hablan sus escritos con sus propios ojos o si algunos detalles «solo $\gg$ los conoce de oídas, pero que integra con la misma fuerza de persuación en su relato de viajes. La evaluación epistemológica de ojo y oído es vacilante incluso en la historia del Occidente9 : No debemos valorar el relato de Ibn Battūta con estas normas que ni son transhistóricas, ni transculturales y no esquematizarlo como sujeto moderno en la definición que se ha acuñado en el mundo occidental.

Pero, ¿de qué manera está estructurado el texto a su nombre desde el punto de vista literarioviajero o bien vectorial? Una enorme estructura circular que le sirve de base a la figura en movimiento a lo largo de todo el relato de viajes árabe-asiático, se abre y se cierra en Tánger, para posteriormente reabrirse hacia una forma circular en el viaje andaluz y a continuación hacia el círculo geográficamente más amplio del viaje africano, donde culminan los viajes. Así se puede leer al principio de la transcripción de los apuntes literario-viajeros del siglo XIV, revisada en el siglo XVII por Muhammad ibn Fath Allah al Bailuni y traducida por Ralf Elger al alemán en el siglo XXI:

\footnotetext{
8 Estas dudas las plantea entre otros el editor de la edición aquí citada; véase Elger, Ralf: Conclusiones. In: Ibn Battūta: Die Wunder des Morgenlandes, op. cit., p. 216-240; Cf. también Euben, Roxanne L: Journeys to the Other Shore: Muslim and Western Travelers in Search of Knowledge. Princeton: Princeton University Press 2006, p. 63-89; así como Ette, Ottmar: ReiseSchreiben. Potsdamere Vorlesungen zur Reiseliteratur. Berlin - Boston: Walter de Gruyter 2020, p. 19-100.

9 Cf. el tercer capítulo “Ojo, oído y lugar del escribir” en Ette, Ottmar: Literatura en movimiento Espacio y dinámica de una escritura transgresora de fronteras en Europa y América. Madrid: CSIC 2008, p. 93 ss.
} 
Salí de Tánger, donde nací, en junio de 1325, con el objeto de peregrinar a la Santa Casa y de visitar el sepulcro del Enviado de Dios, solo, sin compañero con cuya amistad solazarme ni caravana a la que adherirme, pero movido por una firme decisión en el alma y porque el ansia de encaminarme a aquellos nobles santuarios anidaba en mi pecho. Me decidí, pues, en la resolución de abandonar a mis amigas y amigos y me alejé de la patria como los pájaros dejan el nido. Aún vivían mis padres y hube de soportar el dolor de tenerlos lejos, por lo cual todos tres caímos enfermos. A la sazón mi edad era de veintidós años. ${ }^{10}$

Vida y viaje son puestos aquí en una relación intensa, íntima y recíprocamente condicionada. Asimismo, comienza el relato del viaje más extraordinario del siglo XIV, cuyos testimonios nos han sido legados de una forma muy clásica: con un viaje peregrino pío a la Santa Sede del Islam, el Hadsch, con lo cual se inaugura el viaje, que se cierra al final con una segunda peregrinación a Mecca. No es casualidad que de esta forma todo el viaje es puesto bajo la protección de Alá y su profeta Mahoma, una trascendencia divina que en repetidas ocasiones se inserta y rememora en el relato de viaje. En este sentido se trata de un viaje pío e impuesto por Dios.

Tánger se convierte así en el punto de partida de un viaje que, inducido por la nostalgia y añoranza, se extiende más allá de Meca y Medina. Tánger significa asimismo origen y procedencia, que a lo largo del viaje - tal y como hemos podido comprobar - se mantiene vivo en la conciencia del lector. Entre más se alarga el viaje (de vida) de quien al principio del mismo tiene 22 años, más se convierte Tánger en el mito de un origen y también de un futuro, que se inaugurará en el momento de su retorno (no solo desde el punto de vista económico), porque el relato de viaje ha sido dedicado al mandatario local y el autor tiene la esperanza de conseguir algún apoyo que le brinde una vida sin penas en la vejez - Ibn Battūta en ese momento ya tenía más de 50 años de edad. El viajero y erudito, ¿no ha aportado algo grandioso al nivel de conocimientos de su época en todo el mundo islámico?

Ya en la descripción de la entrada a la ciudad de Qandshanfu, el actual Jianshan, se pone de relieve la técnica de exposición precisa utilizada por Ibn Battūta, quien integra siempre un máximo de informaciones culturales, civilizatorias, económicas y sociopolíticas en los movimientos estructurados literario-viajeros. En varias ocasiones se ha puesto de relieve que estas informaciones y detalles no solo se apoyan en lo visto, sino también en lo oído y en lo leído, ya que Ibn Battūta evidentemente no solo fue un lector docto de las fuentes europeo-cristianas, que incluyen entre otros también el relato de viaje de Marco Polo.

Para el musulmán creyente, quien juzgaba despectivamente y en no pocas ocasiones con hostilidad todas las demás confesiones y creencias, la pregunta por la convivencia, por las formas y normas del convivir entre diferentes religiones y también diversas creencias dentro del Islam jugaban un rol decisivo. En China y también en la India y otros países a lo largo de su recorrido, observa muy bien las condiciones de vida y trabajo de sus correligionarios en interacción con otras comunidades religiosas.

Así no sorprende que en Qandschanfu anote con precisión dónde viven los musulmanes, quienes son sus representantes políticos y religiosos y qué importancia ha adquirido la comunidad de feligreses musulmanes en cierta ciudad o región. Nos proporciona así datos fundamentales de una convivencia de las culturas que - tal y como lo demuestra la gran cantidad de experiencias viajeras y

10 Ibn Battūta: A través del Islam, op. cit., p. 110 
narrativas entretejidas - siempre se considera como precaria. Sin un saber con/vivirin es casi imposible organizar una convivencia en paz y en diferencia - esto sale de relieve precisamente en las formas de representación islamocéntricas de Ibn Battūta. Y el relato de viaje del erudito árabe ha contribuido en gran medida a tal saber con/vivir.

Volvamos una vez más a la ciudad Qandschanfu. Después de que el viajero se ha informado acerca de las fortalezas y el número de guardias y pernoctado en la casa del comandante en el primer barrio de la ciudad, le siguen informaciones relevantes para la convivencia en cuanto al establecimientos de la ciudad en 6 barrios:

[...] al día siguiente accedimos a la segunda ciudad por una puerta dicha "De los Judíos. Aquí residen judíos, cristianos y los turcos adoradores del sol, que son muchos. El emir de esta ciudad es un chino a cuya hospitalidad nos acogimos para pasar esa noche. Al tercer día pasamos a la siguiente ciudad - donde viven los musulmanes - que es bonita, con bien ordenados zocos al modo de los propios de países musulmanes. Hay mezquitas y almuédanos. Allí nos hospedamos en asa de los hijos de Utman b Affan, el Egipcio, mercader muy principal al que gustó esta ciudad afincándose en ella, por lo que es conocida con su nombre. ${ }^{12}$

Ibn Battūta siempre trata de entrar en contacto con las élites militares, políticas, religiosas o económicas: ellas le ofrecen un conocimiento específico de control así como las más variadas informaciones concretas, que él incluye de una u otra forma en el relato de viaje. A pesar de que se trata de una visión del mundo centrada en el entorno árabe y orientada en las formas y normas de convivencia musulmanas, demuestra qué tan complejas son las sociedades citadinas visitadas por él y, según sus investigaciones, qué numerosos eran los grupos de pobladores que las componían.

A la vez invoca una y otra vez - así también algunas páginas antes de la visita a la gran ciudad china - el apoyo de las fuerzas divinas que, siendo él un hombre creyente, le señalan a través de las más diversas figuras, incluso por un jeque de supuestamente 200 años de edad, la ayuda de Alá en todas sus empresas ${ }^{13}$. El viaje de vida de Ibn Battūta revela ser desde esta perspectiva una peregrinación inmensamente larga, cuya meta no son solamente los lugares santos, sino todo el mundo de un dios dadivoso y protector del viajero: también en los límites (islámicos) de China. La convivencia en este mundo se desarrolla por lo tanto desde la perspectiva de una trascendencia anclada en el islám. De ahí el rigor en la fe y la moral del autor, quien en no pocas ocasiones actúa amonestando para que se vuelva a la verdadera doctrina del profeta. Desde el extremo poniente hasta el extremo oriente y de regreso: Ibn Battūta cruza el saber de su época no solamente en sentido espacial.

El viaje de retorno después de finalizar su segunda peregrinación a la santa sede del islám lleva a Ibn Battūta a su patria, pasando por Alejandría y la isla de Djerba, una figura de movimiento de disposiciones circulares, al que se adjunta el desmesurado elogio del mandatario al viandante trotamundos, para quien su amo enfarda (como en un espejo ustorio) todas las virtudes y cualidades de los soberanos de los lugares por él visitados y quien supera con creces a todos los demás reyes,

\footnotetext{
11 Para este término, véase Ette, Ottmar: ZusammenLebensWissen. List, Last und Lust literarischer Konvivenz im globalen Maßstab (ÜberLebenswissen III). Berlin: Kulturverlag Kadmos 2010. La traducción al püortugués se publicará hacia findes del 2020 en Curitiba.

12 Ibn Battūta: A través del Islam, op. cit., p. 731.

13 Ibid.
} 
emperadores o califas. Inmediatamente después resuena la alabanza a la patria, que es tan bella, que - tal y como lo formulara Ibn Battūta con el verso del poeta Uthman ibn Dschwawisch - incluso las estrellas comienzan y finalizan su viaje de este lugar: "El sol se mueve hacia allí, las medias lunas parten de allí hacia su viaje"14 .

Tánger, en más de un sentido, es un lugar en movimiento. En esta proyección de sus movimientos terrenales hacia lo celestial, expresada con gran lirismo, el viajero le rinde homenaje al Magreb, esto es, aquel occidente del mundo árabe, en el que el sol brilla más antes de esconderse en el mar. Así, el viandante de Tánger, que ha viajado tanto y personifica el conocimiento de su tiempo, hace una reverencia al final de su viaje frente a su soberano, su origen y su patria.

Sin embargo, en el trayecto de la capital Fes, donde "solté el bastón"1s a Tánger, donde el yo visita "la tumba de mi padre" ${ }^{16}$ se abre - como ya dijimos - una segunda vez el círculo del viaje. Porque el viajero se dirige a Ceuta, que deliberadamente se ha entretejido en las contemplaciones del límite oriental del mundo, para participar, como buen musulmán, en el Dschihad, en la Guerra Santa ${ }^{17}$ contra los infieles, los cristianos. Desde hace mucho, Tánger y Ceuta se encuentran a corta distancia del frente bélico.

Así, Ibn Battūta desarrolla, ante el telón de fondo de la «Guerra Santa» contra los infieles, el paisaje de su región de procedencia a ambos lados del estrecho. Desde una de las columnas de Hércules se puede divisar la otra, el "Dschabal Tariq"18; nombre que homenajea la gloriosa conquista de Tariq en 711 y la consiguiente expansión árabe en la Península Ibérica. Repetidas veces se tiene que combatir y obligar al retroceso "al maldito enemigo"19 en presencia de Ibn Battūta. Aun logra mantenerse el reino de Granada, la capital de al-Andalus, de una belleza "sin par" ${ }^{20}$ con sus fuertes y palacios, sus jardines y su entorno loados por diversos poetas. Al lado de la ciudad de Tánger, Ceuta y Gibraltar son símbolos de aquel mundo que podemos considerar como la región patria de Ibn Battūta entre el Atlántico y el Mediterráneo: la región de procedencia que para él evidentemente era impensable sin la contracosta norte del Magreb, sin el reino nazarí de Granada.

El camino de retorno emprendido después de su participación en la «Guerra Santa» contra los cristianos cruzando el Estrecho de Gibraltar, todavía no significa la vuelta definitiva de Ibn Battūta, ya que de pronto se extiende frente al viandante la gran ruta de las caravanas que cruza el Sáhara hasta el África subsáhara, pasando por Mali y la ruta a Tombuctú que se puede abandonar en el entronque con una ruta que corre más al oriente. Así, le sigue una prolongada estancia en estos lejanos lugares del África que tradicionalmente estaban bien comunicados con el norte del continente. Finalmente, el soberano de Ibn Battūta le ordena en 753 que retorne al palacio, por lo que parte inmediatamente pasando por el "país de los Hoggar" ${ }^{11}$ hacia Fes, "la ciudad residencial del soberano de los creyentes"

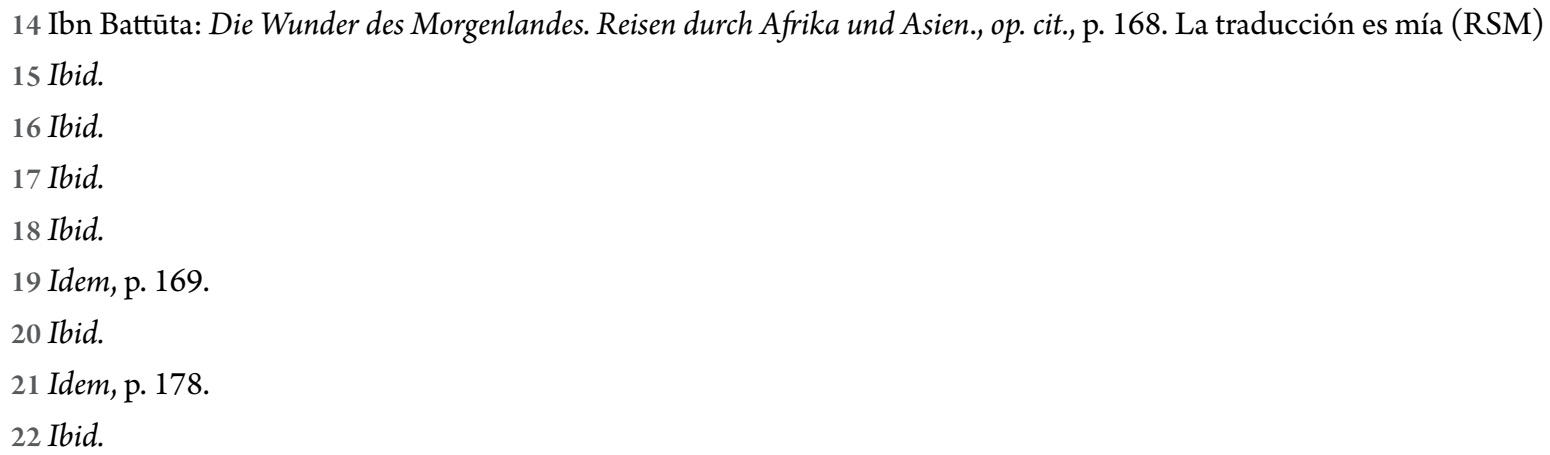


para arribar todavía en ese año al reino. Allí termina el gran viaje de este hombre oriundo de Tánger, una ciudad que puede considerarse tanto como movimiento como en movimiento.

Durante su viaje que durara varias décadas y se interrumpiera una y otra vez a causa de prolongadas estadías y diferentes cargos y misiones encargadas por los más diversos soberanos, el viajero no solo reunió informaciones que al final iría a ofrecer a su soberano en la patria y más tarde, de forma escrita a un público lector. Más bien es de trascendental importancia el tráfico de informaciones, ya que el erudito árabe disponía de conocimientos valiosos, que más de una vez podía vender lucrativamente. Así, por ejemplo, en el trayecto al «Lejano Oriente», después de su viaje por el país de la «Horda Dorada» y una visita a Bizancio, Ibn Battūta fue a visitar a un sultán en su residencia: "Cuando llegué, el sultán me interrogó acerca de mi viaje a Constantinopla y sus gobernantes. Yo le facilité las informaciones requeridas y él me restituyó, como era usual, los viáticos”..23

De esta manera, las rutas de viaje relacionan diferentes regiones, diversas culturas y a veces reinos amigos entre sí con reinos enemigos. Para ellos, el viandante se convierte en comerciante de informaciones y con ello en procurador del conocimiento muy bien remunerado. Viaje y viáticos se interrelacionan.

Para estos prolongados viajes es fundamental el uso de vialidades ya existentes. Las rutas en Asia y en África, así como los caminos de peregrinaje a Meca y Medina, están de antemano determinados. Los viajeros siguen aquellas rutas y cauces por las que ha transitado una miríada antes de ellos. Por eso no ha de asombrar justamente en una metrópoli grande de China, en la que se han asentado los representantes de las más diversas creencias, el reencuentro de un hombre de Tánger y un hombre de Ceuta quienes, gracias a su encuentro, interrelacionan la ruta de la seda con el estrecho de Gibraltar. Quien provenga de Tánger o Ceuta, es conciente del alto valor de las informaciones que circulan a lo largo de las rutas de comunicación, de las vías terrestres o marinas.

Porque el estrecho de Gibraltar enfardaba ya en tiempos de Ibn Battūta desde hacía milenios aquellas corrientes del saber que unían el oriente con el occidente y el sur con el norte. Tánger y Ceuta desde siempre están ubicados en la intersección de estas rutas y por eso se han acostumbrado a fungir como lugares de tránsito. En esta polirrelacionalidad existente desde la antigüedad radica buena parte de su capital mítico. Solo puede convertirse en mito lo que es tema de conversación en la lejanía.

Por eso, Tánger es sobre todo una ciudad en la encrucijada de las corrientes del saber que convierten a la ciudad ubicada en la entrada al Mediterráneo en un espacio de movimiento de las más diversas dinámicas. En este sentido, Tánger es menos una ciudad y más un espacio de tránsito para el intercambio no solo de mercancías y bienens, de viajeros y refugiados, sino asimismo de aquellas formas y normas del saber de vida, que se ha venido desarrollando y compactando de una manera muy particular a lo largo de los siglos y milenios. No es casualidad que el más célebre viajero y escritor de viajes del mundo árabe, que sabía del valor del saber y avanzó hasta los confines del mundo conocido en aquel entonces en el oriente, fuera oriundo de Tánger. Porque Tánger, como ninguna otra ciudad en las encrucijadas de movimientos transcontinentales actuales y pasados, se ha convertido en símbolo del movimiento en sí: del tránsito del conocimiento y su vectoricidad. En su historia y en su mito, Tánger no es territorial, sino vectorial: Tánger es tránsito.

23 Idem, p. 70. 


\section{PARIS EN TÁNGER}

Tánger, fundado en el siglo V. A.d.C. por los cartagineses en la boca occidental del estrecho de Gibraltar, bautizado con el nombre de Tingis y que en la actualidad cuenta con aproximadamente un millón de habitantes. En la mitología griega se conoce como el sitio en el que Hércules partió el mundo en dos y donde, según Píndaro, se hallaban las llamadas «columnas de Hércules» o, según la geografía, las rocas de Calpe y Abyle (hoy en día, Gibraltar y Bjebel Musa) que marcaban los confines del mundo: Non plus ultra. La inquieta historia de esta ciudad al margen del mundo habitable es una historia de constantes cambios de poder, de los que aquí solo tomaremos en consideración unos cuantos. A partir de 702, esto es, apenas unas décadas antes del comienzo de la conquista de la Península Ibérica, cayó en manos de los árabes, pero hubo frecuentes cambios de dominio a lo largo de la Reconquista y en 1471 pasó a manos de los portugueses ${ }^{24}$, en 1580 de los españoles y en 1661 de los ingleses antes de que en 1684 fuera tomada por los alauí. No sería difícil escribir desde Tánger una historia de las relaciones transmediterráneas ${ }^{25}$.

Tánger, manzana de la discordia más bien simbólica entre las potencias europeas de tendencias colonialistas en las postrimerías del siglo XX, se convirtió en «Zona Internacional» en 1923 y desde ese momento ha sido administrada por Francia, Gran Bretaña, España, Portugal, Holanda, Bélgica, la Unión Soviética y desde 1928 también por Italia. Tánger se presenta como ciudad internacional con ancestrales tradiciones de lugar de tránsito, pero también como ciudad con límites geográficos, culturales y políticos. Durante la Segunda Guerra Mundial, Tánger se convierte, sobre todo con el puerto de altura Casablanca, en intersección para el flujo de refugiados de la más diversa procedencia en busca de transportes trasatlánticos. Se establecen también los fundamentos que convertirán a Tánger en un sitio nostálgico de escritores en su mayoría europeos y estadounidenses en los años cuarenta y cincuenta y más tarde, en los sesentas y setentas: bajo el signo de la libertad y de las libertades, Tanger desde hace mucho se había convertido en un mito literario y en un mito de la literatura no solo en Occidente.

Sin embargo, nuestra meta no es el análisis del Tánger tantas veces evocado por Paul y Jane Bowles, Jack Kerouac o Tennessee Williams, Truman Capote o William S. Burroughs ${ }^{26}$. Tampoco se quiere realizar un estudio amplio de la literatura referida a Tánger, sino que se expondrán a modo de ejemplo dos escritores que descubren otro trozo de la historia y del mito de Tánger en el sentido de una vectoricidad, en continuidad con los escritos de Ibn Battūta. Por lo tanto, aquí se hablará de Tanger Transit - y también se formulará la pregunta, por qué vías y cauces vectoriales se puede considerar un sitio arcaico, un sitio mítico, un sitio literario en movimiento, desde el movimiento y como movimiento. Y trataremos de descubrir de qué modo se puede sustituir una historia del espacio

\footnotetext{
24 Referido a la historia de la ciudad de Tánger véase entre otros Elbl, Martin Malcolm: (Re)Claiming Walls: The Fortified Medina of Tangier under Portuguese Rule (1471 - 1661) and as a Modern Heritage Artefact. In: Portuguese Studies Review (Ontario) v. XV, n. 1-2 (2007, p. 103-192; así como (íd.): Portuguese Tangier (1471 - 1662): Colonial Urban Fabric as Cross-Cultural Skeleton. Toronto - Peterborough: Baywolf Press (2013); Brini, Abdellatif: Tanger: urbanisme, relations ville-campagne et histoire comparée d'un paysage urbain. Paris: Ecole Pratique des Hautes Etudes - La Sorbonne 1996; Rickmeyer, Stefan: Nach Europa via Tanger. Eine Ethnographie. TübingIn: Tübinger Vereinigung für Volkskunde 2009.

25 Cf. Hofmann, Franck / Messling, Markus (eds.): Leeres Zentrum. Das Mittelmeer und die literarische Moderne. Eine Anthologie. Berlin: Kulturverlag Kadmos 2015.

26 Cf. la síntesis en Coury, Ralph M. / Lacey, Kevin R.: Writing Tangier. New York: Peter Lang 2009.
} 
por una del movimiento para poder desarrollar no solamente lógicas de lo móvil, sino también lógicas móviles y polilógicas que no se encuentran ancladas en sistemas de referencia estáticos.

Nuestro segundo ejemplo inicia en un bar que, por el constante ir y venir, sin duda puede considerarse un espacio de tránsito. Si se describiese ese bar como localidad, esto es, a partir de su arquitectura, no se sabría nada acerca de ese preciso bar, ni de lo que sucede en los bares en general. Imaginémonos, por consiguiente, a un hombre sentado en un taburete de bar con los ojos entrecerrados:

Un día, a medias dormido sobre el asiento de un bar, intentaba por juego enumerar todos los lenguajes que entraban en mi audición: músicas, conversaciones, ruidos de sillas de vasos, toda una estereofonía cuyo lugar ejemplar es una playa de Tánger (descrita por Severo Sarduy). Todo esto hablaba en mí (es bien conocido) y esta palabra llamada "interior" era muy semejante al ruido de la plaza, a esa gradación de voces que me venían del exterior: yo mismo era un lugar público, un suk; pasaban en mí las palabras, los trozos de sintagmas los finales de fórmulas, y ninguna frase se formaba, como si ésa hubiese sido la ley de ese lenguaje. Esta palabra, muy cultural y muy salvaje a la vez, era sobre todo lexical, esporádica, constituía en mí, a través de su flujo aparente, un discontinuo definitivo $[\ldots]^{27}$

¿Qué es este «discontinuo definitivo»? El pasaje introductorio a la Figura 33 ( «Frase») extraído de El placer del texto de Roland Barthes, cuya publicación data de 1973, a primera vista parece ser una escena en la que el aburrimiento de un hombre se convierte en punto de partida de un juego que el yo juega consigo mismo. Pero, en este texto tan famoso del teórico de los signos, escritor y filósofo Roland Barthes, el cerrar los ojos y guiar la atención hacia el oído crea lúdicamente un paisaje, o más precisamente, un paisaje de sonidos en el que se aglutinan en el oído los más diversos lenguajes, ruidos y trozos de música y de esta manera (usando las palabras de Jean-Luc Nancy) se crea un simultáneo «adentro $\gg y \ll$ afuera $\gg^{28}$. La contingencia de este soundscape es intencional: no se trata de una investigación científica del semiólogo francés, sino de una reflexión teórico-cultural a la vez que científico-vital en busca de la formulación de una estética del placer.

En la perspectiva interior del yo se vuelve visible y audible una perspectiva exterior del intelectual ya tan famoso en aquel momento, perteneciente a la última generación francesa que dominaba el mundo de la teoría cultural y literaria que con él, con su muerte en 1980, se ha eclipsado. No obstante, no debemos confundir este «yo» con el escritor de viajes real, Roland Barthes. En este primer microtexto de tres, que conforman la figura «Frase», se narra una anécdota de Tánger, un biografema que se refiere a los frecuentes viajes de Barthes a Marruecos y en reiteradas ocasiones en compañía de otros intelectuales y escritores como Michel Foucault, François Wahl o Severo Sarduy, especialmente a Tánger.

La disposición experimental realizada por el «yo» se asemeja a la de la «Cámara de los ecos» que Barthes describiera tan admirablemente dos años más tarde en su autobiografía experimental Roland Barthes por Roland Barthes ${ }^{29}$. En los oídos del yo se origina un paisaje de sonidos estereofónicos,

27 Barthes, Roland: El placer del texto seguido por la Lección Inaugural. México: Siglo XXI 1993, p. 80. Existe una edición crítica de este texto de Barthes, Roland: Die Lust am Text. Aus dem Französischen von Ottmar Ette. Kommentar von Ottmar Ette. Berlin: Suhrkamp Verlag 2010.

28 Cf. para esta tensión el volumen, inspirado por Roland Barthes, de Nancy, Jean-Luc: Zum Gehör. Zürich-Berlin: diaphanes 2010, p. 20-31.

29 Barthes, Roland: Roland Barthes por Roland Barthes. Barcelona: Ed. Kairós 1978, p. 84. 
como el que Barthes retomará en su última figura en El placer del texto de forma erotizante y la referirá justamente bajo el término de la estereofonía a una estética del placer a crear en el futuro.

Sin embargo, la referencia a un texto del escritor cubano, amigo de Barthes, Severo Sarduy, puesta entre paréntesis, revela que el texto breve de Barthes se ha desparramado sobre aquel texto de Sarduy, publicado en un número especial de la revista Tel Quel dedicado a Barthes en 1971, con el sencillo título «Tánger». En este texto escrito originalmente en español y más tarde traducido por Philippe Sollers y el propio Severo Sarduy al francés, encontraremos en un juego intertextual de las escondidas precisamente ese término utilizado por Barthes:

Estereofonía del Zoco Chico: el suelo está inclinado; la plaza, a la escucha (a l'écoute) de dos ciudades. Voces que se anulan bajo la voz, siempre presente, de Oum Kalsoum. Las chilabas se relejan en las piedras lisas, después de la lluvia. Comienzan a cantar las suras los pequeños sopranos de la escuela coránica. Las cucharitas entre las hojas de albahaca, en los vasos de té caliente y dulzón. Otras lenguas, pero habladas con una voz ronca, de montañés o de analuz; un castellano tan etéreo que boca se dice oreja y oreja nariz...

Estereografía de afiches lacerados - restos de tipografía latina - caracteres árabes aún chorreantes, trazados con alquitrán. Rayas, franjas anchas y móviles, como en las chilabas de lino [...]. ${ }^{30}$

En unas cuantas líneas se construye, de forma densa y sustrayéndose a la oración como principio ordenador, un paisaje urbano de Tánger por medio de los sonidos, que ahora de hecho llegan hacia nosotros como en una estereofonía: tanto el texto de Sarduy como el de Barthes se pueden escuchar de forma alterna en una estereografía intertextual que asimismo permite oír y leer a Tánger como ciudad de diversas culturas, diversas lenguas, diversas formas de vida. Es el intento de una abertura vocal drástica de la escritura: así, póstumamente se le agrega un texto breve de François Wahl, escrito bajo el signo de la muerte, un texto que se suma intertextualmente como desde el off, en tanto remite al vaso de té en Tánger, en una retrospección que en 1993 avisa la muerte de los amigos ocurrida hace mucho $^{31}$. El tintinear de la cucharita al chocar contra el vaso con las hojas verdes de té. Lo común en los textos de Barthes, Sarduy y Wahl es la búsqueda del tiempo perdido como un signo sensual, como la magdalena introducida en el té en A la Recherche du Temps Perdu de Marcel Proust; obra que para Roland Barthes se convertirá en obsesión en su afán por encontrar una écriture literaria propia.

Así se genera en otro nivel intertextual una estereofonía adicional: un texto llama a otro, un texto le contesta a otro y todos se dan cita en una plaza pública en Tánger, que en El placer del texto se ubica en un bar que convierte el espacio interior del yo en una cámara del eco. ¿Es mera casualidad que el nombre Barthes comience precisamente con las mismas letras? ¿Mera casualidad que en el lexema «bar» se pueda oir el eco de su nombre? El susurro interior del yo se asemeja a los sonidos, genera un «susurro de la lengua», tal y como lo describiera Barthes en el texto del mismo nombre Le bruissement de la langue publicado en 1975: "El susurro es el ruido que produce lo que funciona bien." ${ }^{32}$ Intelectuales parisinos en una plaza, en un café, en un bar en Tánger: Tánger aparece en el susurro de las lenguas, en el que se puede escuchar y está presente el eco de lejanas estereofonías, lejanas estereografías.

30 Sarduy, Severo: Tanger. In: El Cristo de la rue Jacob. Caracas: Monte Avila Latinoamericana 1992, p. 39-40.

31 Véase Wáhl, François: Avant que. In: Magazine littéraire (Paris) 314 (octobre 1993), p. 32.

32 Barthes, Roland: El susurro del lenguaje. Más allá de la palabra y de la escritura. Barcelona: Paidós 1994, p. 100. 
Ya el texto de Sarduy inicia desde la primera línea con una vocinglería de múltiples lenguas, que aquí citaremos sin traducir: "El Zoco Chico, le Petit Socco, place de la Medina, à Tanger; Roland Barthes y a reconnu le «lieu de l'écriture». / Tracer ses coordonnées. Relever sa topologie symbolique." ${ }_{33}$ Obviamente no debe faltar en el juego intertextual de las topologías simbólicas de Sarduy la alusión a Tanger de William S. Burroughs. Es un mundo de referencias y reverencias mutuas, hundidas profundamente en aquel barroco y rococó ${ }^{34}$, que se derrama en siempre nuevos círculos, elipses y volutas - sin faltar la ingeniosa mofa de costumbre: "Mihrab de baquelita. Mucharabíes de poliéster" 35 .

No podremos profundizar más ni extendernos en el hecho de que Barthes en Le Plaisir du texte y Sarduy en «Tánger» querían liquidar la frase como fundamento de toda narración ${ }^{36}$. De mayor importancia para nuestras replexiones resulta ser que las voces de afuera y las voces de adentro en la figura «Phrase» conforman un sitio, por lo que el yo de cierta manera se convierte en un lugar público, en un "Souk" ${ }^{37}$, similar al de Tánger y por lo tanto en un lugar de tránsito. Sin embargo, los jirones, las virutas y los fragmentos no forman una oración, se rehúsan - tal y como sucede en el pasaje estereofónico de Sarduy - a doblegarse ante las leyes de construcción de frases; aceptan otra ley, aquella que prescinde de la frase y que conforma una escritura fractal. Lo esporádico y con ello lo archipiélico de esta lengua permiten que se cree de forma microtextual un discontinuo, como el que intercala Barthes repetidas veces en esta figura (y en muchas otras figuras): Tánger se convierte por ende en un "lugar de escritura" y se transforma en estos textos breves en un fractal: en el modèle réduit de todo un mundo que entra a través del oído a la cámara de eco del yo y que allí encuentra su resonancia polifónica y polilingüe.

Así, tal y como lo manifiesta Severo Sarduy al inicio de «Tánger» con miras a Roland Barthes, todo se convierte en un zoco, en un mercado de lenguas, de las interminables circulaciones de lo sensual, de los sentidos y del sentido - por lo menos en los momentos, cuando este sentido (francés: sens) se piensa como sentido direccional y en plural. Y, de esa manera se añade a «Tánger» de Severo Sarduy y a El placer del texto, de Roland Barthes otro volumen literario-viajero, que Barthes mantuviera oculto hasta su muerte en 1980 y en el que Tánger se convierte en el punto de referencia. Aquí no sorprende que todo comience con la figura (sonora) de un barman ${ }^{38}$ quien, en su mugriento bar de estación, coloca cariñosamente una flor de geranio carmesí en un vaso con agua.

Los Incidentes, publicados recién después de la muerte de Barthes, contienen según el primer editor, François Wahl "lo visto y oído en Marruecos": todo aquello que había sido anotado en los años 1968 y 1969 "fundamentalmente en Tánger y Rabat y después en el sur” ${ }^{39}$. Así, como se ha podido observar en Severo Sarduy, también en Barthes hay muchas escenas reunidas alrededor del Petit Socco, donde en aquel entonces vivían sobre todo aquellos escritores extranjeros que convertirán a Tánger

\footnotetext{
33 Sarduy, Severo: Tanger, op. cit., p. 40.

34 Ibid.

35 Idem, p. 40

36 Cf. para ello en extenso Ette, Ottmar: Kommentar. In: Barthes, Roland: Die Lust am Text, p. 325-333.

37 Véase también, desde otra perspectiva, Landmann, Antje: Zeichenleere. Roland Barthes' interkultureller Dialog in Japan. MünchIn: Iudicium Verlag 2003, S. 129-132.

38 Barthes, Roland: Incidents. Paris: Editions du Seuil 1987, p. 23; para la dimensión específicamente fractal, véase Ette, Ottmar: WeltFraktale. Wege durch die Literaturen der Welt. Stuttgart: Metzler 2017.

39 Wahl, François: Note de l'editeur. En Barthes, Roland : Incidents, op. cit., p. 8.
} 
en un mito para el Occidente. Pero allí donde antaño estaba situado el Foro del Tingis romano, todo había venido a menos sin que por ello quedaran en el olvido los tiempos memoriales de Tánger. Todo esto lo anota con precisión en los "incidentes" marroquíes.

No obstante, los textos breves y brevísimos dan fe de aquella fascinación que despertó el sitio en el narrador y sin lugar a dudas también en Barthes. Así, este lugar mítico en la historia de Tánger desde la primera página se convierte en el escenario de lo que es incomprensible por medio de una lógica simple:

En la plaza del pequeño Socco, una camisa azul como figura de desorden: un muchacho lleno de odio (esto es, con rastros de total enajenación) gesticula y ofende a un europeo (Go home!). Desaparece. Algunos segundos después, los cantos anuncian el acercamiento de un entierro; aparece el cortejo fúnebre. Entre los portadores del féretro (que se turnan) el mismo muchacho, temporalmente en sus cabales. ${ }^{40}$

Este pequeño incidente en la plaza alude sobre todo a las tensiones entre «nativos»y «europeos», pero al mismo tiempo pone de relieve el funcionamiento de una lógica al menos doble. Sin embargo, aquí no se trata tanto de la construcción de una realidad extralingüe referenciable, sino más bien de una textualidad que apunta, como la teoría del texto de Tel Quel, a la liberación del significante de la presión ejercida por la mímesis y, quizás más aun, en el sentido de El placer del texto a un sortear la ordenadora frase. En los microtextos y microcuentos se menciona una y otra vez explícitamente Tánger; pero este Tánger funciona como una disposición experimental, como un laboratorio en el que se producen constantemente nuevos incidentes a nivel textual. El placer del texto radica en lo siempre novedoso y diferente y también en la irreductibilidad a una única y dominadora lógica. Así, este volumen conforma, con la sucesión de microtextos y micronarraciones definitivamente discontinuas, una pieza valiosa de literatura de viaje experimental ${ }^{41}$. Todo está colmado de movimientos, pero se niega a cualquier intento por reconstruir los movimientos de viaje del viajero. El «desorden» no se transfiere a un «orden».

Tánger y su Petit Socco son símbolo de un mundo compartido por marroquíes y europeos, por pobres, ricos y bohemios vivido con todos los sentidos y en toda su sensualidad. Con frecuencia, las micronarraciones cuentan acerca de transgresiones de fronteras de distinta índole, tal y como lo representan de estas dos micronarrativas que se suceden una a la otra:

En la playa de Tánger (familias, tías, jóvenes), trabajadores viejos que se asemejan a insectos muy viejos y muy lentos, limpian la arena.

Selam, un veterano de Tánger, prorrumpe en risas, porque había tenido un encuento con tres italianos que le robaron su tiempo: «Pensaban que era una mujer! ${ }^{42}$

Fronteras entre géneros, entre animales y hombres, entre lenguas y culturas, entre afiliaciones sociales y políticas, entre lógicas, ortodoxias e ideologías que sin cesar se transgreden y desafían el sentido en favor de los sentidos. Movimientos con el coche o con el avión, con el tren o el taxi insertan movimientos de viaje a manera de un cruce por una ciudad, que no se logran subsumir en un movimiento de viaje. Las micronarraciones se niegan a un solo sentido, a un solo movimiento, a una

\footnotetext{
40 Barthes, Roland: Incidents, p. 23. La traducción es mía (RSM)

41 Cf. Ette, Ottmar: Roland Barthes. Landschaften der Theorie. Konstanz: Konstanz University Press 2013, p. 105; Roland Barthes.

Paisajes de la teoría. Bogotá: Cajón de Sastre 2020.

42 Barthes, Roland: Incidents, op. cit., p. 31 s.
} 
sola lógica: desde el principio, Tánger es un sitio polilógico, en el que una sola lógica occidental de identidad e identificación lleva al absurdo.

Así, Tánger se convierte en un microcosmos de placer textual que permite también echar una mirada al placer (homo) sexual. Por lo tanto, so se dejan compatibilizar las lógicas del cuerpo con las políticas del cuerpo, con la política y el ahorcamiento de posibles víctimas inocentes por una justicia dependiente:

\begin{abstract}
Abdellatif - tan voluptuoso - justifica categóricamente los ahorcamientos de Bagdad. La culpabilidad de los acusados es evidente, porque el proceso ha sido muy rápido: es por eso que el caso era claro. Incoherencia entre la brutalidad de esta tontería y la tibieza fresca de su cuerpo, la disponibilidad de sus manos que yo continúo, con bastante indiferencia, sosteniendo y acariciando mientras él pronuncia su catecismo vengador. ${ }^{43}$
\end{abstract}

En mente, el breve juicio hecho al inculpado. En el cuerpo, sin embargo, el placer - y el placer del texto:"El placer del texto es ese momento en que mi cuerpo comienza a seguir sus propias ideas pues mi cuerpo no tiene las mismsa ideas que yo". ${ }^{44}$ Los Incidentes marroquíes se encuentran en intenso intercambio en los más diversos niveles con Le Plaisir du texte. Los Incidents de Barthes remontan pues a sus viajes por Marruecos en los años 1965"5, 1968 y 1969, sobre todo a una estancia más larga en Rabat, en donde Barthes, profundamente decepcionado por los acontecimientos en mayo del 68 en París, comenzara su labor como docente invitado por un año. Al igual que Japón, Marruecos le ofrecería al intelectual francés en los años sesenta la posibilidad de reorganizar los horizontes atópicos ${ }^{46}$, utópicos y sobre todo heterotópicos de su pensamiento, partiendo del sentido densificado de ciertas islas en su calidad de paisajes polilógicos de la vida. El microcosmos de Tánger y en él sobre todo el mundo alrededor del Petit Socco conforman aquí estructuraciones radicalmente abiertas que convierten Tánger en fractal de una filosofía, de una teoría del texto, que se rebela contra la racionalidad dominante de Occidente: por una dépossession de l'Occident ${ }^{47}$ que aspira y propaga Barthes a nivel de la frase, de la razón, de una aplastante lógica.

Tal y como sucediera en su texto temprano En Grèce (En Grecia) ${ }^{48}$ que de cierta manera contiene sumariamente tanto su programa de escritura corta como las formas del movimiento de su pensamiento archipiélico, aparecen Tánger y también Rabat y Marrakech como islas metropolitanas, como paisajes urbanos insulares. No obstante, se mantienen en una peculiar e imprecisa discontinuidad que recorta estas ciudades como islas de su continente y se escenifica literariamente en forma de una fractalidad de múltiples quiebres: Marruecos como archipiélago que no se puede someter a ninguna lógica continental. De la misma manera que Japón es una isla, Tánger lo es también con sus playas, sus plazas, su gente.

43 Idem, p. 36.

44 Barthes, Roland: El placer del texto, op. cit., p. 29.

45 En sus reportes anuales para la EPHE, Barthes apunta un seminario visitante en noviembre de 1965 en la Facultad de Letras de Rabat (OC II, p. 111).

46 Cf. Oster, Angela: Ästhetik der Atopie. Roland Barthes und Pier Paolo Pasolini. Heidelberg: Winter 2006.

47 Barthes, Roland: Sollers écrivain. Paris: Seuil 1979, p. 47. Véase además, Ette, Ottmar: Roland Barthes. Eine intellektuelle Biographie.

Frankfurt am Main: Suhrkamp 2a. edición 2007, p. 23.

48 Barthes, Roland: En Grèce. En (íd.): Oeuvres complètes, t. I, p. 54-59. 
En Tánger, por momentos chocan dos mundos con súbita violencia: se pueden vivir muy de cerca las líneas de tensión entre Europa y el Magreb y también entre América del Norte y África del Norte: Tánger es un espacio de movimiento trasatlántico. Los diversos mundos chocan entre sí con asperidad y violencia en los microtextos - y precisamente de este choque, de este encuentro se crea aquello que quisiéramos denominar un paisaje archipiélico de la teoría pero ya no mediterráneo, sino transareal ${ }^{49}$, esto es, formado por la vinculación de diversas partes del mundo. Con su Petit Socco, Tánger se ha convertido en un fractal de tipo transareal: aquí se pueden experimentar sensualmente las líneas de tensión entre diferentes mundos. La desposesión del mundo esquematizada por Barthes también afecta a los «bohemios» de las sociedades occidentales que se apropian, en el sentido literal de la palabra, de la ciudad:

En el pequeño Socco en julio, la terraza esta repleta de gente. Se sienta un grupo de hippies, entre ellos una pareja; el marido es un rubio gordo, desnudo debajo de su overol, la mujer trae un largo camisón tipo wagneriano, de su mano una niña, blanca y suave; la deja cagar en la banqueta, entre las piernas de sus compañeros, a quienes no les importa. ${ }^{\mathbf{5 0}}$

Roland Barthes, quien probablemente terminara sus Incidentes en 1969, había delineado este mirocosmos de contrarios en ese mismo año en un ensayo para la revista parisina Communications, en el que advertía, bajo el título Un cas de critique culturelles1, sobre las aporías de la civilización occidental, que seguía mostrándose dominante y hegemónica incluso en los contra-movimientos. ¿No se podría relacionar esto también con otros movimientos que criticaban el Occidente y al mismo tiempo practicaban la domina e incluso la multiplicaban? Tal y como Barthes lo realizara en los textos brevísimos de sus Incidents, también trató de poner de relieve en el artículo el movimiento hippie revelando las contradicciones de su crítica cultural desde un punto de vista que probablemente nunca hubiera tenido sin el saber de vida y el saber de vivencia que le proporcionaran sus viajes a Marruecos. El intento de Barthes por expropiar el Occidente incluye una crítica a los críticos occidentales con un estilo de vida occidental. Por eso, Barthes perfila en sus Incidentes un Tánger plagado de hippies que corrían tras el mito de la ciudad, que se habían apoderado temporalmente de ella y daban rienda suelta a su forma de vida imponiéndola como norma de vida. Los hippies aparecen aquí como invasores agresivos de Occidente. Los marroquíes y también los intelectuales parisinos desde hace mucho que ya no estaban tranquilos.

La escritura corta, practicada con más radicalidad en los incidentes marroquíes que en cualquier otro texto literario-viajero le ofrece al público lector enormes espacios en blanco que puede rellenar con creatividad: no tardó mucho y estos vacíos fueron «rellenados » con datos biográficos - no solo con miras a sus relaciones amorosas en su mayoría homosexuales ${ }^{52}$ y heteroculturales que constantemente aparecían en la superficie del texto. No cabe duda que Tánger no fue para Barthes un lugar del «Noli

49 En cuanto al término de lo transareal, véase Ette, Ottmar: TransArea. Eine literarische Globalisierungsgeschichte (2012) y su versión inglesa (2016) o francesa (2019).

50 Barthes, Roland: Incidents, op. cit., p. 30.

51 Barthes, Roland: Un cas de critique culturelle. En (íd.): Oeuvres complètes, t. II, p. 544-546.

52 Desde muy temprano predominó una lectura autobiográfica de estos pasajes que en unión con otros textos de Barthes, se interpretaban casi como «confesiones ; Cf. Knight, Diana: Barthes and Orientalism. In: New Literary History (Charlottesville (XXIV), 3 (1993), p. 622. 
me tangere» (No me toques). Sin embargo, reducir la ciudad de Tánger y su significado para Barthes al nivel del placer y del amor homosexual es más que problemático ${ }^{53}$. En vista de la estética bartheana del placer debemos cuidarnos de identificaciones biografizantes demasiado sencillas, porque aquí se trata de un paisaje del texto polilógico, que ya no se puede comprender desde un único punto de vista centrado y siguiendo una sola lógica. También en Severo Sarduy, el Zoco Chico es un laboratorio textual que trata de socavar la perspectiva central de la construcción oracional occidental, las construcciones occidentales del yo y la lógica occidental. En este sentido textual, Tánger se convierte en laboratorio y asimismo en fractal de una teoría parisina, que textualiza placenteramente Tánger.

La complejidad y radicalidad de este texto literario-viajero desvía la atención de los movimientos del viajero que observábamos en un itinerario como el de Ibn Battūta, hacia los movimientos de los lectores, que circulan, allende del discurso publicado por vez primera en 1967 acerca de la «Muerte del autor $\gg^{54}$, por paisajes textuales de la teoría propios. Tal y como sale a relucir en el denso texto de Sarduy, «Tánger», que no en balde le fue dedicado a Barthes, se encuentra almacenado el mito gracias a las referencias y reverencias intertextuales, pero se traduce a un paisaje de la teoría que logra convertir a Tánger en tránsito, pero de otra manera que en Ibn Battūta.

Como texto- isla, Tánger es un mundo-isla en sí con su propio mundo complejo; pero Tánger, como isla-mundo, asimismo pertenece a un mundo de islas global de corte archipélico y proyecta el paisaje polilógico fundamentado en discontinuidades hacia el Petit Socco. Todo aquí se puede escuchar, ver, es sensualmente vivible y vivenciable. Tánger se convierte en un fractal-isla de un mundo que tiene que ser interpretado de la misma manera como el texto de viaje microtextual, desde perspectivas constantemente modificadas. La ciudad portuaria en el norte de Marruecos no se debe fijar como alteridad, como lo otro estable, sino convertirse en un móvil, que no solo puede ser visto, sino vivido como un paisaje de sonidos. Lo que se relaciona con el nombre de Tánger no se oculta, sino que se borra: las rutas de los viajeros no se convierten en rutinas. La ciudad situada en la entrada y salida del Mediterráneo va convirtiéndose, en un sentido mucho más experimental que en la Roma de Pier Paolo Pasolini, en una cittá aperta, en una ciudad abierta en un sentido no solamente transmediterráneo, sino asimismo transatlántico. Para el teórico francés, Tánger es un laboratorio vectorial y, al mismo tiempo, un ejercicio más para echar, desde París, las redes de una teoría post-colonial, como dépossession de l'Occident, sobre las cartografías del mundo.

\section{TÁNGER COMO TRÁNSITO Y COMO PAISAJE DE LA TEORÍA}

Es por eso que aquí realizaremos un salto hacia la literatura latinoamericana que juega un papel más bien marginal en el entorno de los textos dedicados a Tánger. Sin embargo, enmedio de la rica literatura sobre Tánger es precisamente la novela de un destacado autor centroamericano la que traza

53 Véase entre otros, Hargreaves, Alec G.: A Neglected precursor: Roland Barthes and the Origins of Postcolonialism. In: Murdoch, H. Adlai / Donadey, Anne (eds.): Postcolonial theory and Francophone Literary Studies. Gainesville: University Press of Florida 2005, p. 55-64; así como Algalarrondo, Hervé: Der langsame Tod des Roland Barthes. Berlin: Parthas Verlag 2010, entre otras, p. 37 y p. 170.

54 Barthes, Roland: La mort de l'auteur. En (íd.): Euvres complètes, t. II, p. 491-495; véase asimismo Ette, Ottmar: LebensZeichen. Roland Barthes zur Einführung. Hamburg: Junius Verlag 2013, p. 80-88. Para el debate sobre el punto final de la teoría, véase Compagnon, Antoine: Le demon de la théorie. Littérature et sens commun. Paris: Seuil 1998. 
una imagen de la ciudad como sitio de tránsito así como la que vimos en Ibn Battūta y Roland Barthes. A continuación, por lo tanto, nos dedicaremos a la novela publicada en España en 1999, La orilla africana del guatemalteco Rodrigo Rey Rosa. Históricamente, se sitúa después de la dominación francesa de la teoría que, con la muerte de Sartre y de Barthes en 1980, conoce su éclipse que algunos, como p.ej. Antoine Compagnon, interpretaron como el fin de la teoría. Veamos eso de más cerca.

Desde el principio de la novela, Tánger aparece como espacio de movimiento. No obstante, la trama no inicia en la ciudad misma, sino en una franja costera en las inmediaciones de Tánger y por ende se concentra en la ubicación geográfica y topográfica específica de la ciudad portuaria entre el Atlántico y el Mediterráneo. Así se origina en la entrada y la salida del Estrecho de Gibraltar un campo de tensión de contrastes entre el mar, la costa y la ciudad. Porque la costa árida y escarpada no es una región idónea para pastar borregos: expuesta a las ráfagas de viento y al embate de las olas, con rocas por doquier que se erigen majestuosamente contra la embestida de las fuerzas de la naturaleza obliga a la gente y los animales a buscar constantemente dónde refugiarse. Es un mundo expuesto tanto a las corrientes de viento como a las del mar, en los confines del continente africano y exactamente enfrente de aquellas luces, que marcan el extremo sudoccidental de Europa. Ya el título pone de relieve que hay cierta inversión de la familiar perspectiva occidental, porque Tánger enfoca la historia desde las costas africanas.

Una región escabrosa y arcaica, en la que aparece primero la figura de un joven pastor nativo y no la internacional ciudad de Tánger, cuya importancia sale a flote en el trayecto de la novela. La figura del pastor parece proceder de otros tiempos, de la prehistoria, de los inicios de una literatura que en Mesopotamia creara la figura del pastor Enkidu conviviendo con sus animales y a quien se le confiere un papel tan importante en el canto épico del Gilgamesh en cuanto al proceso de civilización y la relación entre campo y ciudad ${ }^{55}$. La figura de Enkido, el amigo de Gilgamesh, está omnipresente.

Hamsa no cuida sus rebaños en las amplias estepas de Mesopotamia (Zweistromland = país de los dos ríos), sino en aquel mundo de tres continentes, en el que se encuentran cara a cara África, Asia y Europa, Marruecos y España, así como las dos columnas de Hércules, La Ceuta española y el Gibraltar británico, que repesentan los residuos de los poderosísimos imperios hispano y británico de antaño. Una y otra vez aparecen ya en el primer capítulo remanentes de antiguas posesiones coloniales de potencias europeas y proporcionan muestras de una historia del colonialismo que, sin embargo, es muy diferente a la que transmite la figura del pastor en tanto representa en el fondo la prehistoria y la temprana historia. Nos encontramos en un sitio verdaderamente arcaico en donde imperan las fuerzas de la naturaleza, pero también de la literatura, del contar bajo el signo del pastor y su rebaño.

Hamsa es sin lugar a dudas la figura más enigmática de esta novela que se desarrolla - si seguimos el prefacio de Pere Gimferrer - en el campo de tensiones entre perspicuidad y misterio ${ }^{56}$. Es desde el incipit del texto escrito por Rodrigo Rey Rosa, quien naciera en Guatemala en 1958, que nos adentramos en el mundo animista e irracional, lleno de ritos sacrificales y amuletos de Hamsa, el pastor:

55 Véase Maul, Stefan: Einleitung. In: Das Gilgamesch-Epos. Neu übersetzt und kommentiert von Stefan M. Maul. MünchIn: C.H. Beck 2005, p. 9-42.

56 Rey Rosa, Rodrigo: La orilla africana. Prefacio de Pere Gimferrer. Barcelona: Editorial Seix Barral 1999, p. 9. 
Hamsa se levantó cuando todavía estaba oscuro y el viento del Este soplaba con fuerza para hacer sonar el follaje de los árboles como mil maracas y silbar entre las peñas del acantilado, al pie del cual se estrellaban violentamente las olas del mar. ${ }^{57}$

Ya el inicio del primer capítulo de los 55 que tiene la novela resalta la violencia y los constantes movimientos presentes en esta costa - en cierto modo en la oscuridad de las historias y de la historia que se convierten en presente. En la negrura al filo de la madrugada no se puede ver nada: todo se sitúa en un paisaje que al principio es pericibido «solo» como un paisaje sonoro, pero marcado siempre por la violencia del viento y las olas del mar en la costa africana del Estrecho.

Aunque el Estrecho de Gibraltar es una de las rutas marítimas probablemente más transitadas del mundo: el argumento de la novela no comienza con la atmósfera bulliciosa en la ciudad de Tánger, donde habita gente de las más diversas regiones del mundo, sino con una naturaleza más bien áspera, en la que se introduce el sonar de las maracas latinoamericanas como un paisaje de sonido transareal. Este soundscape latinoamericano no solamente nos anuncia al protagonista latinoamericano que será presentado más adelante, no únicamente nos proporciona importantes indicios en relación con la figura narradora de este texto, sino nos advierte que este paisaje emergente de la oscuridad es un paisaje de la teoría ${ }^{58}$, en el que podemos reconocer la clave a todos los movimientos en la novela. En el sonido de este paisaje todo se coniverte en presencia y presente, en un afuera y adentro simultáneo ${ }^{59}$, si tomamos en consideración la reflexiones de Jean-Luc Nancy a través del oído. Tanger es aquí al igual que en Ibn Battūta, menos un espacio urbano y más un espacio de movimiento, sin el cual no se puede pensar ni entender todo el paisaje costero y su ubicación intercontinental.

Un corderito del rebaño del pastor se había perdido a la víspera y Hamsa comienza a buscarlo. Para ello tiene que abrirse paso por la maleza y pasar al lado de las ruinas del ex "club náutico español"60 para descubrir que el animal se encuentra, asustado y temblando al pie de un acantilado, "arrinconado entre dos peñas salpicadas intermitentemente por el reventar de las olas" ${ }^{1}$. Es la imagen de una criatura que se siente acorralada y en su desesperación no ve otra salida que lanzarse al mar. En el último momento Hamsa logra sacar al extenuado animal del agua y llevarlo hacia donde está el rebaño. Como en el caso de Enkido, las relaciones entre hombres y animales ${ }^{62}$ juegan un papel decisivo en el desarrollo de la novela: en este vínculo se (re)presentan la vida, la superviviencia y la convivencia desde una perspectiva al mismo tiempo difuminadora y densificante.

El mar no es símbolo solo de las fuerzas de la naturaleza imperantes en este litoral, sino sirve asimismo como fundamento para aquellas fuerzas de la cultura que han convertido las corrientes marítimas al margen de la línea de división geográfica entre África a Europa en una línea troncal de las corrientes de tránsito que unifican esta región de manera transoceánica y transcontinental con todo el mundo. Esto no significa que el puerto de Tánger - que actualmente se está ampliando en grande

57 Idem, p. 17.

58 Cf. en cuanto a este término Ette, Ottmar: Roland Barthes. Landschaften der Theorie, op. cit., p. 49-60.

59 Cf. Nancy, Jean-Luc: Zum Gehör, op. cit., p. 20-31.

60 Idem, p. 18.

61 Ibid.

62 En cuanto a la relevancia de los Animal Studies véase Meyer-Krentler, Leonie: Die Idee des Menschen in der Karibik. Mensch und Tier in französisch- und spanischsprachigen Erzähltexten des 19. Jahrhunderts. Berlin: Verlag Walter Frey - edition tranvía 2013. 
entre Ceuta y Tánger - pueda participar en todos estos movimientos marítimos, pero todos estos movimientos inscritos desde la antigüedad hasta el momento actual y proyectados hacia el futuro han logrado conformar un paisaje vectorial complejo que no se puede entender como un espacio estático.

Así como es visible de día el campo y de noche las luces de Europa, así tanto de día como de noche las grandes embarcaciones surcan su camino por el estrecho marítimo. Europa está omnipresente: también en aquellos movimientos que se han establecido diagonalmente a los ya mencionados. Porque en la noche aparecen los contrabandistas, como el tío de Hamsa que le trae al joven pastor de la otra orilla cercana no solamente las imitaciones baratas de los zapatos tenis Nike que Hamsa cuida celosamente, sino también los sueños de una vida llena de riqueza, una vida con vehículos caros y bellas mujeres rubias: sueños que sin lugar a dudas se sueñan del lado africano de Gibraltar y que en el siglo XXI siguen siendo igual de atractivos.

Es impensable la orilla africana sin su contraparte europea - y viceversa: en su campo de tensión se fusionan los movimientos transmediterráneos y transatlánticos. La enclave de Ceuta, ocupada por los españoles y Gibraltar, en manos de los ingleses, dan fe de la importancia geoestratética que tienen todas estas posiciones y movimientos para los cálculos tácticos de poder de las potencias coloniales europeas del pasado. Una y otra vez se intercala este paisaje de la teoría en la novela, se visibilizan desde la lejanía del Jebel Musa, la pálida torre de Hércules que ha sido arrojada a la orilla africana ${ }^{63}$ y los buques blancos que se alejan rumbo a Gibraltar dejando una larga huella cremosa ${ }^{64}$. Como en los mapas del estrecho, la superficie del mar está llena de líneas de buques que lo surcan.

El autor guatemalteco que, huyendo de la violencia en Guatemala y amplias regiones en Centroamérica, encontrara refugio en Marruecos y se ocupara intensamente de la historia de este país, construye a través de 55 capítulos breves y discontinuos una historia que intercala las diferentes fases de la historia de esta región fronteria entre los mares, entre los continentes, entre los ricos de forma asimismo sutil y subversiva. A la visión de Tánger y su alrededor áspero y escabroso se le agrega, por medio de la mención del antiguo club náutico español ${ }^{65}$, la espansión del colonialismo hispano, portugués, francés o inglés; se remite a las viejas vías romanas por donde transitaban los miles de leones capturados en el norte de África para las arenas del imperio; se mencionan las embarcaciones en las que miles de marroquíes, miles de africanos desafían la suerte para llegar a la Tierra Prometida de la otra orilla. Aún no son los enormes éxodos del siglo XXI, pero estos caben muy bien en el cuadro migratorio descrito en 1999 en La orilla africana.

La novela sigue todos estos movimientos, por lo que se origina un cuadro de movimiento complejo y por momentos desconcertante, en el que no pueden faltar los turistas, los nómadas, los migrantes y los refugiados de Europa, de Estados Unidos y de América Latina. Se trata aquí de un espacio altamente vectorizado donde, debajo de los movimientos actuales se perciben y observan los movimientos del ayer, que al mismo tiempo se almacenan para el futuro. Desde el principio el espacio de Tánger se escenifica desde los más diversos puntos de vista como un paisaje de desplazamiento

63 Rey Rosa, Rodrigo: La orilla africana, op. cit., p. 64.

64 Ibid.

65 Idem, p. 18. 
transareal tanto de lenguas como de culturas, de formas y normas de vida, de lo real y de lo soñado. Tánger se convierte en un lugar en el que puede localizar lo transareal en un entremundos.

Esta transarealidad no se limita únicamente a la relación norte-sur entre África y Europa, porque este continente no está conectado solo por mar sino también por aire con todo el mundo. No es sorpresa por lo tanto que un centroamericano no envíe a un norteamericano sino a un sudamericano a Tánger y haga que quede encandilado de este espacio de movimiento. Al lado del marroquí Hamsa y la joven francesa Julie, que vive en la mansión de la adinerada Madame Choiseul, situada en un ambiente idílico, donde los abuelos de Hamsa se tienen que ganar el pan de cada día y de su jubilación, este viajero colombiano, que al parecer ha perdido su pasaporte, es la tercera figura central que completa una constelación triangular entre África del Norte, Sudamérica y Europa occidental no solo con miras a un amor esperado y añorado, sino también en cuanto a su procedencia. Para todos, con excepción de Hamsa, Tánger significa tránsito. Una configuración azarosa, pero no transareal por azar.

El encuentro de estas tres figuras es igualmente transitorio, así como los hoteles y alojamientos de mala muerte, en los que el colombiano pasa el tiempo después de haber perdido su pasaporte, su vida anterior y una meta en su vida. Sus experiencias con las prostitutas marroquíes, a quienes podía pagar mientras poseía suficiente dinero, son un componente importante de aquella Trans(it)Area ${ }^{66}$, en la que se dan cita los protagonistas antes de que se pierdan de vista otra vez: Tánger es tránsito.

Así, el tiempo en este espacio de movimiento es siempre también tiempo prestado: un tiempo acuñado por los movimientos de reunión y separación que no conoce una linealidad temporal general, obligatoria. Al final de un diálogo con Julie acerca de la presencia de la Antigüedad y sus vínculos transmediterráneos se voltea el colombiano y mira desde las alturas hacia Occidente: "donde se abría el mar" ${ }^{67}$. Y se da cuenta que probablemente está disfrutando por última vez esta vista del mar y sobre los tiempos. El mar es la superficie de movimiento que es capaz de crear todas las relaciones transareales, pero también de interrumpirlas. Lo único perdurable es el tránsito.

Por consiguiente, la aventura amorosa de la joven francesa con el sudamericano - en cuyas manos ve por primera vez el búho herido del cual quedará fascinado - es de poca duración: no más larga que el consumo conjunto de drogas ligeras en el hotelucho sucio del colombiano. En un abrir y cerrar los ojos se ha terminado el idilio, que desde la perspectiva europea alude a los tiempos míticos de Tánger, y desde el punto de vista colombiano a la historia del tráfico de drogas entre Tánger y Colombia. Tal y como sucede en Severo Sarduy, también aquí se funden las drogas ligeras con las seducciones ligeras (drogue y drague en un "DR(A/)GUE”)68. Tánger no le ofrece ninguna perspectiva a largo plazo a esta pareja dispareja, reunida por el azar. La novela de Rodrigo Rey Rosa tiene inherente el mito, lo conjura pero lo vuelve a perder: la gran libertad no la encuentra ninguno de los protagonistas de $\mathrm{La}$ orilla africana.

Tánger es un espacio de viajeros - un área de tránsito - y, por consiguiente, de las ficcciones. $A$ beau mentir qui vient de loin. En un espacio, en el que revolotean los cuentos, en el que los ingleses tienen

\footnotetext{
66 Véase aquí Ette, Ottmar / Mackenbach, Werner / Müller, Gesine / Ortiz Wallner, Alexandra (eds.): Trans(it)Areas. Convivencias en Centroamérica y el Caribe. Un simposio transareal. Berlin: Verlag Walter Frey - edition tranvía 2011.

67 Rey Rosa, Rodrigo: La orilla africana, op. cit., p. 124.

68 Sarduy, Severo: Tanger, op. cit., p. 87.
} 
ocupada una roca con el nombre de un conquistador árabe y que los españoles demandan para sí pero quienes a su vez mantienen ocupada la otra columna de Hércules en las orillas africanas, las fronteras no son estables ni estáticas a largo plazo. Tampoco los linderos entre hechos y ficciones, entre poesía y verdad, entre lectura y vida. ¿Cómo podrían serlo? Son hechos en tránsito, verdades temporales, vida de lo leído. Los libros que se encuentran tirados en el suelo en el cuarto del hotel del colombiano, al parecer surtieron efectos difusos en él. Las ficciones y autoficciones de su mundo imaginario se han apoderado desde hace mucho de él:

No le gustaba mentir pero a veces la verdad acerca de sí mismo le parecía inaceptable y entonces se lo permitía, siempre con la intención de cambiar las cosas para que sus ficciones llegaran a coincidir con la realidad. Podía no estar casado, como lo estaba de hecho, ni ser un simple turista con el pasaporte extraviado. Se miró en el espejo.

La verdad de las mentiras y las verdades inventadas que se convierten en mentiras de la vida conforman una textualidad inextricable. La vida en Tánger ya no se logrará poner en consonancia con la vida en otra parte, por ejemplo, con su trabajo anterior, con su mujer anterior en Colombia. Hechos y ficciones ya no se pueden dividir los unos de los otros: en Tánger todo se ha convertido en tránsito. También la mirada al espejo, que había ayudado a recobrar la identidad a tantas otras figuras novelescas, no esclarece, sólo es un reflejo. Se refleja una calavera en la cara del vivo de la misma manera como la muerte le sonríe incesantemente a la vida.

Desde hace tiempo que las ficciones se han apoderado de su vida: malas ficciones que no ha sabido aprovechar para sí y que no proporcionan ningún esclarecimiento a su vida. Tánger al parecer ha arrojado al colombiano fuera de su vida anterior, sin haberlo catapultado hacia una nueva: ningún futuro, no se perfila ningún futuro promisorio. A pesar de que las viejas mentiras se diluyen en el horizonte occidental: Tánger para él solo es la sucesión de cuartos de hotel cada vez más pobres, por consiguiente de espacios de tránsito que se abren siempre a nuevos esepacios de tránsito.

Sin embargo, allí donde ya no se puede distinguir un punto de orientación en el ámbito interpersonal, gana en importancia la relación entre seres humanos y animales, que desde el principio se había podido visualizar entre el pastor y su rebaño. El colombiano al parecer sólo le puede ser fiel a la lechuza capturada que compra por poco dinero, cuida cariñosamente de ella - incluso después de que le expulsan del hotel por culpa del animal. El búho desde hace mucho se ha convertido en aquel objeto de deseo que a la vez une y separa a Hamsa, Julie y al colombiano, ya que el buho dispone de poderes de los que pueden sacar algún provecho todos, aunque de forma muy diversa.

La diégesis novelesca marroquí con su relacionalidad norafricana-sudamericana-centroeuropea no conforma únicamente un área de tránsito, sino asimismo una TransÁrea,en la que se cruzan y entrecruzan incesantemente los caminos de los protagonistas, su lenguas y culturas, sus costumbres, entrecruzamientos y concepciones de fe. Debajo de cualquier nombre de calle, debajo de cada calle en Tánger aparecen otras calles, otros nombres, obras lenguas y otras culturas El espacio urbano de Tánger demuestra ser tanto un perpétuum mobile tanto multilingüe como multicultural que no sólo se encuentra en constante movimiento, sino también tiene que ser contemplado desde perspectivas móviles, en movimientos.

La apertura polilógica de Tánger no incluye únicamente los más diversos orígenes europeos o americanos, sino que incluye concepciones e imaginaciones religiosas judías, cristianas e islámicas en 
incesante comunicación interrumpida. Cada objeto, cada costumbre, cada historia puede ser contemplada desde diversas perspectivas de forma diferentes, sin convertirse en una lógica obligatoria para todos. Lo arcaico y lo animista está presente de la misma manera que el agnosticismo o la ortodoxia. La ciudad se convierte por consiguiente en un círculo del mundo urbi et orbi, en el que el tránsito se convierte en un fractal, en modelo reducido de un mundo que no sólo se une sino que asimismo se separa aquí. La convivencia descansa aquí en la contingencia.

Las figuras de la novela se convierten en configuraciones, cuya convivencia se mantiene siempre en un estado precario y discontinuo. La novela desarrolla de esta manera una convivencia transitoria, que en la estructura discontinua de 55 capítulos breves no se somete a ninguna lógica singular. Tal y como sucede en Incidents de Roland Barthes, todo choca contra los linderos de aquello que se podría denominar con mayor precisión una constelación de violencia. Esta violencia que está presente desde el inicio en la novela, acuña asimismo la convivencia que permite que persistan múltiples lógicas una al lado de la otra. La convivencia por ende se mantiene en un estado precario, descansa en un tiempo prorrogado, del que nadie sabe decir cuánto tiempo perdurará este estado - hasta que en el horizonte aparezcan nuevas fuerzas y con ello nuevas formas de la violencia. Tánger se encuentra en el lado africano de la historia occidental, en la región más occidental de Levante, en la parte atlántica del Mar Mediterráneo: la ciudad nos obliga a despedirnos y distanciarnos de cualquier tipo de perspectiva centralista.

La novela de Rodrigo Rey Rosa realza una y otra vez los movimientos transitorios pasajeros: no solamente en la sucesión de los cuartos de hotel, sino de todo tipo de pasajes, de naturaleza efímera como por ejemplo los recorridos en taxi que ofrecen espacios de tránsito móviles en los que tienen lugar y se pueden vivir encuentros espacialmente delimitados: Tanger Taxi: el capítulo XXXVII, de apenas una página de longitud, perfila desde el punto de vista de la lengua, un viaje de tal índole, un encuentro que al parecer comienza en árabe. El taxista le pregunta a su nuevo cliente:

Tú, ¿eres marroquí? / No. / Tunecino? / no. / Egipcio? / No. / ¿De dónde eres? / De Colombia. / ¿Pero hablan árabe en Colombia? / No. Español. / Aquí también hablamos español dijo el taxista en español tangerino. ¿Cómo es la vida en tu país? /Más o menos como aquí. / Horrible, entonces. / Es verdad. ${ }^{69}$

Es un diálogo breve, casi en staccato, en el que las afiliaciones nacionales y las lenguas nacionales ya no justifican una identidad, sino que a lo más posibles orígenes. El taxista no logra adivinar la procedencia de su cliente. ¿Pertenecerá el protagonista latinoamericano a aquel grupo de inmigrantes tan importante, que huyeron a finales del siglo XIX de las guerras civiles en el Medio oriente y sobre todo de Líbano a las costas caribeñas de Colombia o a Centroamérica o a Chile? Las relaciones árabeamericanos ${ }^{70}$ evocados en este pasaje que cuentan con una larga tradición y aquí se intercalan como por casualidad, remiten sin embargo a las condiciones de vida que tanto en Marruecos como en Colombia es igual de horrible. Se escenifica Tánger como una ciudad transareal pero ya no más como mito, sino más bien desmitificada. Tánger Transit: El mito de Tánger parece haber llegado a su fin: "Horrible, entonces" - tan horrible como cualquier otro lugar.

69 Idem, p. 109.

70 Véase para ello Ette, Ottmar / Pannewick, Friederike (Hg.): ArabAmericas. Literary Entanglements of the American Hemisphere and the Arab World. Frankfurt am Main - Madrid: Vervuert Verlag - Iberoamericana 2008. 
Por eso, la novela no finaliza en Tánger sino que retorna a la escarpada región costera en la boca del Estrecho de Gibraltar. Lo que une a los tres protagonistas es, tal y como ya se ha dicho, un animal al que se le atribuyen fuerzas mágicas y por lo tanto fuerzas vitales: el enorme y siempre fascinante búho, que durante su cautiverio cambia constantemente de dueño y que, como criatura cautiva al igual que el desesperado cordero, depende totalmente del ser humano. Después del intento fallido de pasar la noche con Julie, quien a cambio de tener relaciones con él pide la libertad del búho robado por Hamsa, será el vuelo en libertad del pájaro ya sano con el que se cierra la novela del autor guatemalteco de una forma sobrecogedora y polisémica. Así, el texto narrativo tan fascinante que comenzara antes del amanecer, termina en el ocaso con el vuelo del búho sobre aquel terreno escarpado en el que había empezado la acción:

Se lanzó al vacío y voló con el viento hacia la luz que moría donde terminaba la tierra y sólo estaba el mar. Remontó el vuelo al pasar sobre el cobertizo del pastor, y, desde lo alto, alcanzó a ver a la mujer que ya se había calzado y andaba de prisa por el filete de hierba que bordeaba el camino asfaltado entre los muros. Se elevó hasta la cumbre del monte y vio, en la distancia, las luces vidriosas que iluminaban las colinas cubiertas por un manto de casas blancas que se perdían entre los pliegues del campo sediento y agrietado. Bajó para volar sobre las copas de los árboles hacia una casona abandonada en medio de un bosque tupido. Entró por una ventana y fue recibida por los gritos de los pájaros que ya anidaban allí. Recorrió la casona volando de cuarto en cuarto por los pasillos hasta que encontró una hendidura conveniente en la pared áspera y oscura de un desván, donde faltaban algunas tejas y las tablas del piso estaban rotas o completamente podridas. ${ }^{71}$

El vuelo del pájaro vuelve a crear una vez más y desde el movimiento, -esto es, no hay una única perspectiva-, aquel espacio en el que coinciden y se vuelven a perder de vista los protagonistas de $\mathrm{La}$ orilla africana. La omnipresencia de una naturaleza que, aunque maltratada por los hombres, sigue impasible hace que al final de la novela la ciudad de Tánger vuelva a desaparecer en el horizonte. Así como ya sucediera al principio de la narración, al final se perfilan las ruinas de las construcciones humanas, los rastros de la convivencia humana, pero ahora se convierten en guarida para los animales que se recluyen en el pasado Los movimientos del animal inician y concluyen la novela, aunque será difícil que el búho se deje capturar de nuevo. En su vuelo, logra atisbar a Julie quien se aleja de prisa después de haber estado a punto de entregarse al pastor, huyendo de las dimensiones del órgano viril circuncidado de éste -al parecer había surtido efecto la receta que había utilizado ${ }^{72}$ y un grano purulento en su testículo (descrito con la misma nitidez con la que antes se hablara de los pezones invertidos de Julie $)^{73}$. Estaba libre aquel pájaro por cuya libertad ella se iba a entregar; la gente no podía convivir con ella, así como tampoco lograban la convivencia entre ellos. La virilidad del pastor probablemente es una herencia tardía de vieja(s) historia(s); no obstante, no se logra unir con la joven, y tampoco logra integrarse a la civilización urbana ${ }^{74}$, cuyos sueños normados comparte con los demás. A diferencia de los otros personajes de la novela, que en su profundo desgarramiento son seres sin residencia fija que

\footnotetext{
71 Rey Rosa, Rodrigo: La orilla africana, op. cit., p. 157.

72 Idem, p. 21.

73 Idem, p. 103.

74 Véase el canto épico de Gilgamesh, p. 52.
} 
pierden su camino en el espacio de tránsito, sólo el pájaro logra encontrar una casa y convertirla en su residencia fija.

A través del búho vuelve a traslucir aquella sabiduría que se vincula desde tiempos inmemoriales con el vuelo. Aunque fracasen todos los intentos de los protagonistas por apropiarse del conocimiento sobre la convivencia; aunque las figuras femeninas no logren, tal y como lo hiciesen en el canto épico del Gilgamesh, liberar por medio de ardides a los seres masculinos del lastre que los oprime para llevarlos al placer, al final de esta novela ensamblada por breves capítulos, el mundo se reúne en el vuelo del búho; un mundo que en su fragmentarismo transareal es un "mundo hecho añicos",75 tal y como lo formulara hace algunos años Clifford Geertz.

Así, en la larga tradición a la que se une Rodrigo Rey Rosa, el mundo es sujetado por los movimientos de un pájaro; en la obra de viaje de Alexander von Humboldt es un papagayo el único que domina la lengua de los extintos atures ${ }^{76}$; Mário de Andrade le erige a este papagayo de Humboldt al final de Macunaíma ${ }^{77}$ un monumento casi continental; Max Aub sólo puede observar el mundo del univers concentrationnaire en su Manuscrito $\mathrm{Cuervo}^{78}$ a través de la perspectiva de un cuervo y Cécile Wajsbrot, en Mémorial79, cautiva un mundo frío y congelado en la silueta, los movimientos mínimos y las miradas de un búho nival. Lo destruido, lo perdido se comprime por última vez en la mirada de un pájaro; porque en estas obras, los personajes, a pesar de hacer grandes esfuerzos, no logran una convivencia pacífica entre hombres de diferente procedencia, diferente cultura, diferente religión. Sólo desde la perspectiva del pájaro en vuelo se puede unir todo el desgarramiento terrestre.

En esta novela, La orilla africana, Rodrigo Rey Rosa continua con su afán de proyectar un mundo y sus contradicciones, sus conflictos y fragmentos en un ritmo narrativo, que logra reunir fractalmente una totalidad de procedencias y diferencias a través de los 55 capítulos breves, cuya longitud varía de 1 a 5 páginas. La diégesis de Marruecos, su área de tránsito, en donde el autor guatemalteco vivió por varios años como exiliado voluntario y también la estructuración conformada por áreas transareales, pertenecientes a diferentes ámbitos culturales y geográficos, hacen que surja un espacio de experimentación, en el que se pueden ensayar y observar los límites de un saber con/vivir. El mito de Tánger está discretamente presente, pero al final desaparece tras el horizonte de su propia historia en un denso paisaje de la teoría.

No es ninguna casualidad que el autor centroamericano no eligiera el istmo americano como diégesis para su experimento, sino la orilla africana, el estrecho entre África y Europa, quizá como tardío reflejo de las tempranas representaciones cartográficas del Caribe y Centroamérica, en las que el centro del continente se reproducía ya sea como istmo o como estrecho. ¿Dónde, sin embargo, se podría situar este "paso" hoy en día?

75 Cf. Geertz, Clifford: Welt in Stücken. Kultur und Politik am Ende des 20. Jahrhunderts. WiIn: Passagen-Verlag 1996.

76 Véase Humboldt, Alexander von: Ansichten der Natur, mit wissenschaftlichen Erläuterungen. NördlingIn: Franz Greno 1986, p. 192 y $210 \mathrm{~s}$.

77 Considérese una edición más reciente de la novela modernista de Andrade, Mário de: Macunaíma - o héroi sem nenhum caráter. Brasília: Col. Arquivos CNPQ1988.

78 Aub, Max: Manuscrito Cuervo. Historia de Jacobo. Introducción, edición y notas de José Antonio Pérez Bowie con un Epílogo de José María Naharro-Calderón. Segorbe - Alcalá de Henares: Fundación Max Aub - Universidad de Alcalá de Henares 1999.

79 Wajsbrot, Cécile: Mémorial. Paris: Zulma 2005. 
Con su literatura sin residencia fija, Rey Rosa logra desasirse de las ataduras a una diégesis americana y personal tan frecuentes en la literatura centroamericana, para crear una temporalidad espacial al parecer "ajena" por medio de los movimientos transareales. De la primera a la última frase, los movimientos conforman un espacio altamente vectorizado, en el que traslucen los remotos movimientos que cruzan el África del Norte desde hace siglos en los movimientos de los protagonistas. No en balde, la joven Julie es estudiante de arqueología y su plan es encontrar, bajo las calles actuales, las calles del ayer. $Y$, sin embargo, el vuelo del búho pone de relieve una dimensión que supra el tiempo del hombre y asimismo deja trás de sí en forma de una ruina bien visible la historia de Tánger cruzada por las temporalidades y por las estructuras de poder.

Por eso, el afán de la novela de crear una totalidad de lo experimentado, lo inventado y lo vivido se mantiene radicalmente abierto en el vuelo del búho. Éste, que a diferencia del hombre vive de noche y no de día, encuentra su nuevo hogar en una casa y con ello en aquel ámbito que el ser humano se construye para habitarlo y con/vivir en él. Después de todos esos siglos de saqueos, invasiones y la explotación tanto colonial como postcolonial, la novela le otorga la última palabra a la sabiduría del búho, porque él logra convivir bajo un mismo techo con aves de otras dimensiones, de otros colores, de otras procedencias. ¿será éste el nuevo Tánger - un Tánger de los animales? ¿O solamente anuncia una nueva cronometración del tiempo que comenzará allen de Tánger?

En cautiverio y aherrojado, el búho había unificado las vidas de los tres personajes; cuando se ve libre de ataduras y emprende el vuelo hacia su libertad, también se disuelven las relaciones entre los protagonistas. A partir de este momento ya no hay nada que reúna las rutas de la vida de estas personas -más que su existencia nómada en un transitar transareal, que encuentra su mise en abyme en el estrecho de Gibraltar. Tánger es tránsito; y lo mismo sucede con su mito, que a pesar de que siga resonando, es transitorio. En la conciencia de este tránsito empero se perfila aquel desafío de Ibn Battūta frente a Tánger, pasando por el de Roland Barthes y Severo Sarduy hasta el de Rey Rosa: El reto de escribir a través de las literaturas del mundo, allende la dominante historia del espacio, una historia del movimiento que sea capaz de conducir hacia una conciencia de mundo nueva, móvil, en consonancia con los movimientos y las migraciones.

Las teorías de la literatura nunca llegan a un punto final: las alimentan siempre las literaturas del mundo. El daimon de la teoría no tiene casa ni patria: si en un país que, durante una temporada, se cree céntrico, parece eclipsarse, reaparece y está más ágil y vivo que nunca en otro país, en otra región, en sus relaciones transareales. Los paisajes de la teoría que nos brindan las literaturas del mundo son infinitos: como los paisajes, presuponen a las viajeras, a los viajeros que los cruzan y que enfocan sus espacios desde perspectivas diferentes. Carecen de cualquier centralidad: prescinden de una perspectiva, de una sola lógica para invitarnos a contemplar e investigar los paisajes de la teoría desde ángulos divergentes - pero siempre con el placer del texto. 


\section{REFERENCIAS}

ALGALARRONDO, Hervé. Der langsame Tod des Roland Barthes. Berlin: Parthas Verlag, 2010

ANDRADE, Mário de: Macunaíma - o héroi sem nenhum caráter. Brasília: Col. Arquivos, 1988.

AUB, Max. Manuscrito Cuervo. Historia de Jacobo. Introducción, edición y notas de José Antonio Pérez Bowie con un Epílogo de José María Naharro-Calderón. Segorbe; Alcalá de Henares: Fundación Max Aub; Universidad de Alcalá de Henares, 1999.

BARTHES, Roland. Paisajes de la teoría. Bogotá: Cajón de Sastre 2020.

BARTHES, Roland. Die Lust am Text. Aus dem Französischen von Ottmar Ette. Kommentar von Ottmar Ette. Berlin: Suhrkamp Verlag, 2010.

BARTHES, Roland. En Grèce. In: Euvres complètes. Paris: Editions du Seuil, 2002, t. I, p. 54-59.

BARTHES, Roland. La mort de l'auteur. In: Euvres complètes. Paris: Editions du Seuil, 2002, t. II, p. 491-495.

BARTHES, Roland: Un cas de critique culturelle. In: Euvres complètes. Paris: Editions du Seuil, 2002, t. II, p. 544-546.

BARTHES, Roland. El susurro del lenguaje. Más allá de la palabra y de la escritura. Barcelona: Paidós 1994.

BARTHES, Roland: El placer del texto seguido por la Lección Inaugural. México: Siglo XXI, 1993

BARTHES, Roland. Incidents. Paris: Editions du Seuil. 1987.

BARTHES, Roland. Sollers écrivain. Paris: Seuil 1979

BARTHES, Roland. Roland Barthes por Roland Barthes. Barcelona: Ed. Kairós 1978

BATTŪTA, Ibn. Die Wunder des Morgenlandes, Reisen durch Afrika und Asien. München: C.H. Beck 2015.

BATTŪTA, Ibn. A través del Islam. ed. y trad. Serafin Fanjul y Federico Arbos. Madrid: Editora Nacional 1981

BRINI, Abdellatif: Tanger: urbanisme, relations ville-campagne et histoire comparée d'un paysage urbain. Paris: Ecole Pratique des Hautes Etudes, La Sorbonne, 1996.

COMPAGNON, Antoine. Le demon de la théorie. Littérature et sens commun. Paris: Seuil, 1998.

COURY, Ralph M.; LACEY, Kevin R. Writing Tangier. New York: Peter Lang, 2009.

DUNN, Ross E. The Adventures of Ibn Battūta: A Muslim Traveler of the Fourteenth Century. Berkeley: California University Press, 1986

EL LIBRO DE MARCO POLO ANOTADO POR CRISTÓBAL COLÓN. El libro de Marco Polo. Versión de Rodrigo de Santaella. Edición, introducción y notas de Juan Gil. Madrid: Alianza Editorial, 1987.

ELBL, Martin Malcolm. Portuguese Tangier (1471-1662): Colonial Urban Fabric as Cross-Cultural Skeleton. Toronto; Peterborough: Baywolf Press, 2013.

ELBL, Martin Malcolm. (Re)Claiming Walls: The Fortified Medina of Tangier under Portuguese Rule (14711661) and as a Modern Heritage Artefact. Portuguese Studies Review, Ontario, v. XV, n. 1-2, p. 103-192, 2007.

ETTE, Ottmar. ReiseSchreiben. Potsdamere Vorlesungen zur Reiseliteratur. Berlin; Boston: Walter de Gruyter, 2020 .

ETTE, Ottmar. WeltFraktale. Wege durch die Literaturen der Welt. Stuttgart: Metzler, 2017. 
ETTE, Ottmar: TransArea. A Literary History of Globalization.Berlin; Boston: Walter de Gruyter, 2016.

ETTE, Ottmar: Roland Barthes. Landschaften der Theorie. Konstanz: Konstanz University Press, 2013

ETTE, Ottmar: LebensZeichen. Roland Barthes zur Einführung. Hamburg: Junius Verlag, 2013.

ETTE, Ottmar; MACKENBACH, Werner; MÜLLER, Gesine; ORTIZ WALLNER, Alexandra (eds.). Trans(it)Areas. Convivencias en Centroamérica y el Caribe. Un simposio transareal. Berlin: Verlag Walter Frey, 2011.

ETTE, Ottmar: Kommentar. In: BARTHES, Roland. Die Lust am Text. Aus dem Französischen von Ottmar Ette. Kommentar von Ottmar Ette. Berlin: Suhrkamp Verlag, 2010, p. 325-333.

ETTE, Ottmar: ZusammenLebensWissen. List, Last und Lust literarischer Konvivenz im globalen Maßstab (ÜberLebenswissen III). Berlin: Kulturverlag Kadmos, 2010.

ETTE, Ottmar. Literatura en movimiento Espacio y dinámica de una escritura transgresora de fronteras en Europa y América. Madrid: CSIC, 2008

ETTE, Ottmar; PANNEWICK, Friederike (Hg.). ArabAmericas. Literary Entanglements of the American Hemisphere and the Arab World. Frankfurt am Main; Madrid: Vervuert Verlag; Iberoamericana, 2008.

ETTE, Ottmar. Roland Barthes. Eine intellektuelle Biographie. Frankfurt am Main: Suhrkamp, 2007.

EUBEN, Roxanne L. Journeys to the Other Shore: Muslim and Western Travelers in Search of Knowledge. Princeton: Princeton University Press, 2006.

GEERTZ, Clifford. Welt in Stücken. Kultur und Politik am Ende des 20. Jahrhunderts. Wien: Passagen-Verlag, 1996.

HARGREAVES, Alec G: A Neglected precursor: Roland Barthes and the Origins of Postcolonialism. In: MURDOCH, H. A.; DONADEY, Anne (eds.). Postcolonial theory and Francophone Literary Studies. Gainesville: Florida University Press, 2005, p. 55-64.

HOFMANN, Franck; MESSLING, Markus (eds.). Leeres Zentrum. Das Mittelmeer und die literarische Moderne. Eine Anthologie. Berlin: Kulturverlag Kadmos, 2015.

HRBEK, Ivan. The chronology of Ibn Battūta's travels. Archiv Orientalni, Praga, v. 30, p. 409-486, 1962.

HUMBOLDT, Alexander von: Ansichten der Natur, mit wissenschaftlichen Erläuterungen. Nördlingen: Franz Greno, 1986.

KNIGHT, Diana. Barthes and Orientalism. New Literary History, Charlottesville, v. XXIV, n. 3, p. 622, 1993.

LANDMANN, Antje: Zeichenleere. Roland Barthes' interkultureller Dialog in Japan. München: Iudicium Verlag, 2003, p. 129-132.

MAUL, Stefan: Einleitung. In: Das Gilgamesch-Epos. Neu übersetzt und kommentiert von Stefan M. Maul. München: C.H. Beck 2005, p. 9-42.

MEYER-KRENTLER, Leonie. Die Idee des Menschen in der Karibik. Mensch und Tier in französisch- und spanischsprachigen Erzähltexten des 19. Jahrhunderts. Berlin: Verlag Walter Frey, 2013.

NANCY, Jean-Luc. Zum Gehör. Zürich-Berlin: Diaphanes, 2010.

OSTER, Angela. Ästhetik der Atopie. Roland Barthes und Pier Paolo Pasolini. Heidelberg: Winter 2006.

REY ROSA, Rodrigo. La orilla africana. Prefacio de Pere Gimferrer. Barcelona: Editorial Seix Barral, 1999. 
RICKMEYER, Stefan: Nach Europa via Tanger. Eine Ethnographie. Tübingen: Tübinger Vereinigung für Volkskunde, 2009.

SARDUY, Severo. Tanger. In: . El Cristo de la rue Jacob. Caracas: Monte Avila Latinoamericana 1992, p. $39-40$.

WÁHL, François. Avant que. Magazine Littéraire, Paris, v. 314, p. 32, 1993.

WAHL, François. Note de l'editeur. In: BARTHES, Roland. Incidents. Paris: Editions du Seuil, 1987, p. 8.

WAJSBROT, Cécile. Mémorial. Paris: Zulma 2005. 